\title{
Lecturer Certification and The Teaching-Learning Process Quality in Universitas Sumatera Utara
}

\author{
Fatma Wardy Lubis ${ }^{1}$, Hendra Harahap ${ }^{2}$ \\ Universitas Sumatera Utara \\ Medan, Indonesia \\ Email: fatmawardy62@gmail.com ${ }^{1}$
}

\begin{abstract}
This research entitled "Lecturer Certification and Quality of Teaching and Learning Process in Universitas Sumatera Utara" is aimed to know the quality of teaching and learning process conducted by certified lecturer at Universitas Sumatera Utara. This research is needed because the Indonesian government is determined to improve the quality of education from basic education to higher education. One important component in determining the quality of higher education is lecturers, because lecturers have an important role in teaching and learning process. Teaching in college is a professional job, therefore it takes a qualified lecturer, that is a lecturer who has the ability in the field of knowledge and teaching skills. Universitas Sumatera Utara was chosen as the location of this research based on the fact that the Universitas Sumatera Utara is one of the oldest and largest universities outside Java, where the position of Universitas Sumatera Utara at the national level among the best state universities in Indonesia, began rivaled by universities other countries outside Java. While in this era of globalization, higher education is required to produce qualified and competitive human resources to play a global role. Therefore, as a respected higher education institution, Universitas Sumatera Utara is considered responsible for providing high quality education and in accordance with market demands.To get an objective and measurable picture of the quality of the teaching-learning process, we used a quantitative research method with 220 people as our sample. Samples are then distributed evenly across four non-exact science faculty namely; Faculty of Social and Political Sciences, Faculty of Economics and Business, Faculty of Cultural Sciences, and Faculty of Law.There are nine indicators in analyzing the teaching and learning process: 1) Accountability; 2) Efficiency; 3) Creativity; 4) Effectiveness in task assignment and group discussion; 5) Consistency;6) Productivity; 7) Clarity and adequacy of information; 8) Compliance with needs and responsiveness; 9) Level of satisfaction.The results show that; In general, the implementation of teaching and learning process by certified lecturers in Universitas Sumatera Utara is very good. However, Universitas Sumatera Utara as an educational institution needs to make improvements, to complement, provide facilities and infrastructure in the learning process. Meanwhile, on the management of human resources, especially certified lecturers should be improved to improve the quality of teaching and professionalism. If this measure is taken, the Universitas Sumatera Utara tends to meet the expected quality and will be able to compete with other higher education institutions in Indonesia and Southeast Asia.
\end{abstract}

Keywords: Certification, Lecturer, Quality of teaching-learning process

\section{INTRODUCTION}

In this era of globalization, universities face challenges that are not easy. Universities are required to produce ready-made human resources (HR) in accordance with market needs and able to play a global role. Therefore, universities including Universitas Sumatera Utara (USU) should be able to make policy in conducting higher education quality and professional.

Lecturer certification is one of the efforts undertaken by the government to improve the quality of national education and encourage improvements in the welfare of lecturers. If the lecturer's welfare level improves, it is expected that lecturers can carry out intellectual tasks in accordance with their competence and professional. Professional behavior is characterized by the ability of lecturers to manage the teaching and learning process well in accordance with the portion of science.

The regulation on lecturers certification is contained in Peraturan Pemerintah (PP) $37 / 2009$ about Lecturers and Undang-Undang 14/2005 about Teachers and Lecturers. These legal laws are the basis for the determination and evaluation of lecturers certification, where the government has required every educational institution to have a certified lecturer.

Lecturer certification leads to improving the welfare of lecturers, where lecturers receive a professional allowance worth the basic salary given every month. Simply put, a lecturer who has been certified gets twice of the salary in one month. Assessment of lecturer certification related to the implementation of Tridharma Perguruan Tinggi that is Education, Teaching, 
Research, and Community Service. It is expected that lecturer certification hences higher education has competent resources. Competent resources can improve the quality of education for students.

The quality of education is not only related to the product produced. One of the most important parts is the process. The process in education and teaching will also determine how the quality of the product is graduates generated higher education. However, in practice, lecturers who have been certified sometimes do not reflect the quality of the learning process. The lecturer process is unable to elicit the ability to analyze, compare, apply a principle and critical attitude of the students. Yet, there is not many new methods and innovations are emerging from the learning process eventhough the class is taken care of by certified lecturers.

Universitas Sumatera Utara as one of the universities that entered the status of PTNBH, is the one of oldest, largest and famous universities outside Java, should has been strengthened by the human resource (HR) of lecturers who have been certified. However, does this lecturer certification has an impact on the quality of teaching and learning in USU? This is highlighted in this research. The point of research is the quality of the on going learning process, whether it is in accordance with the teaching program in college, whether it is effective and efficient.

The results of this research will be submitted to USU as education providers, as inputs, as an evaluation material, and should have implications for policy revision, continuing policy, and dissemination of college learning program policies. For the researcher, the result of this research is expected to be an input to improve the policy related to learning system and certification of lecturers, which will ultimately impact on improving the quality of learning process in USU, and to achieve USU vision as stated in Renstra USU namely: "colleges that have academic excellence as a barometer of scientific progress that can compete in the global world ".

To achieve the vision and mission then formulated the goals to be achieved USU, are follows:

1. Produce qualified graduates who are capable of developing science, technology, humanities and arts, based on religious morals, and able to compete at national and international level;

2. Produce innovative research that encourages the development of science, technology, humanities, and art in national and international scope;

3. Produce dedication to the community based reasoning and research work that is useful in promoting the general welfare and educating the nation's life and community empowerment innovatively so that people can solve problems independently and sustainably;

4. Achieve independence that is adaptive, creative, and proactive towards the demands of society and development challenges, both nationally and internationally.

5. Improve the quality of management learning continuously to achieve excellence in competition and national and international cooperation;

6. Being an intellectual moral force in building Indonesian civil society;

7. Develop the potential of students to become human beings who believe and piety to God Almighty and have a noble, healthy, knowledgeable, skilled, creative, independent, skilled, competent and cultured for the benefit of the nation.

One of the main problems in the world of higher education in Indonesia today is the quality problem of graduates. Colleges should produce graduates who have real skills and are able to compete in the world of work both nationally and internationally. To produce qualified graduates such as this required qualified and professional lecturers. Therefore, a lecturer must have master knowledge in the various abilities of both the ability of the field of knowledge and the ability to teach, because a lecturer should be able to make a plan, can grow a fun learning process, effective learning, efficient, as facilitators, evaluators, and innovators in lectures. In other words, the lecturer is a central figure who plays directly in the learning process. Therefore lecturers become an important component in determining the quality of graduates of higher education.

Along with the increasing number of universities in Indonesia, then each institution is competing through ways of improving academic quality in accordance with the development of science and technology today.

According to Woolfolk \& Nicholic (1984: $59)$ "learning is a change in a person that comes about as a result of experience". The experience gained in the learning process must of course be able to describe the experience as close as possible to the real world. meaning that learning 
should give the feel of the real world of work and very competitive. Learning process is expected to emphasize the happening of intellectual change in class participants by affection, cognition, and conation.

Changes as a result of the learning process can be manifested in various forms, and in general there is in the knowledge of something, the attitude in the situation, skills, acceptance and other aspects of the individual (Nana Sujana \& Ibrahim, 2004: 28) . Then, this is formulated in the concept of the Kerangka Kurikulum Nasional Indonesia (KKNI).

According Kirkpatrick (1988: 20), "learning can be defined as the extend to which participants change attitudes, improving knowledge, and/or increase skills as a result of attending the program".

Like learning, teaching is essentially a process. Teachers in this process should organize both themselves and the conditions that exist around the students so as to foster or motivate students to know, understand, until the change of their behavior.

The learning process can be identified as:

1. The process of sharing and processing information: lectures, discussions, seminary, case studies, practical assignments, research assignments.

2. Internalization processes: exercises, responsibilities, homework assignments, tutorials, peer discussions and group work.

3. Reversal mechanism process: discussion of internalization results, evaluation notes on assignment sheet, announcements and comments; evaluation process is done through: evaluation of result (test or without test) and process evaluation (colleague/student).

In this learning process, students have involvement in various aspects, namely:

1. Involvement of psychomotor aspects and "hands on": practicum, internship, practical work and experimental.

2. Cognitive aspect involvement: intellectual reasoning and mastery comprehensively.

3. Involvement of affective aspects: the exposure of environmental sensitivity, emotional maturity.

In the learning process, activities are carried out systematically, programmed and arranged with specific designs, e.g. FEE design (facilitating, empowering, enabling). The goal is to make students learn actively and to emphasize the learning axis. The process of creativity development of students thinking in improving and constructing new knowledge. The student in learning something is motivated to discover the basic meanings and structural relationships attached to the material and relate it to the structure of his personal knowledge and experience (Elley, 1993). This kind of learning approach enables students to apply high-order thinking skill, which is "a variety of critical thinking skills (Nagappan, 2001).

One of the learning process that intensively developed in college today is the process of student-centered learning.

The characteristics of this model include :

a. Studying individually/group to build knowledge by seeking/digging information and technology needed actively.

b. Lecturers act as FEE (Facilitating, Empowering, Enabling), 'guides on the side' instead of 'mentors in the centery' is help access information, organize and transfer it to find solutions to problems in the real life. The strategic function as a facilitator requires lecturers to keep learning and keep up with the latest developments in their discipline. In addition, the facilitator function requires the lecturer to conduct the process of sharing knowledge with students.

c. Students are not only competent in their knowledge, but also in learning.

d. Learning to be a community activity facilitated by lecturers.

e. Life-long learning (required in the workplace).

f. Learn to take advantage of available technology.

To find out whether the certified lecturer influences the learning process, some academics from various universities conduct research on the certification of the lecturer. Here are some of them; Research conducted by Kadek Sonia Piscayanti et al., Lecturer from Universitas Pendidikan Ganesha (UNDIKSHA), Singaraja, entitled "Influence of Lecturer Certification on Teaching Performance". The results of this study indicate that there is no difference between the performance of lecturers UNDIKSHA before and after the enactment of certification.

Furthermore, research conducted by Muhardi from the Faculty of Economics Unisba University. This study focuses on "The Effect of Certification Allowance on Lecturer Productivity in Produce Scientific Work and Research". The results show that there is a significant difference 
in lecturer productivity to produce scientific work and research after the certification of lecturers. This means that certification of lecturers has encouraged lecturers to be more productive to make scientific work and research.

Research on lecturer certification was also conducted in Institut Pertanian Bogor (IPB) by Ramalia, et al. The title of the study is "Analysis of Lecturer Performance Factors (Case Study of Faculty of Agriculture IPB)". One of the conclusions of the research is: lecturer certification influences lecturer's performance.

\section{THEORETICAL FRAMEWORK}

\section{A.ASSESSMENT AND EVALUATION OF LEARNING PROCESS} TEACHING

Program evaluation is a series of deliberate activities to see the success of the program. Komite Studi Nasional about Evaluation (Stark \& Thomas, 1994) states that:

"Evaluation is the process of ascertaining the decision of concern, selecting appropiate information, collecting and analyzing information in order to report the summary data of useful to decision makers in selecting among alternatives."

Meanwhile, evaluation according to Suharsimi Arikunto (2004: 1) is: activities to collect information about the work of something, which then the information is used to determine the right alternative in making decisions.

Furthermore, Brikerhorf (1986), explains the scope of evaluation, namely: 1) Determination of the focus to be evaluated; 2) preparation of evaluation design; 3) information gathering; 4) analysis and interpretation of information; 5) preparation of reports; 6) evaluation management; 7) evaluate the evaluation process that has been done (evaluating evaluation).

Based on this, it can be seen that evaluation generally aims to: 1) measure the reality of the implementation of the program/activity in accordance with the goals/goals that have been set previously; 2) As input for the decision making process about program/activity, and; 3) To improve the program/activity in the future.

\section{MODEL OF EVALUATION OF CIPP LEARNING PROCESS}

This evaluation model was developed by Daniel Stuffleabem et al at Ohio State University in 1967. This model is considered the most comprehensive model because it is able to provide evaluation stage models ranging from context, input, process, to the end result of the learning process product.
CIPP Model (Context, Input, Process \& Product) by Madaus, Scriven and Stufflebeam (1983) states that, "The CIPP process is based on the view that the most important purpose of evaluation is not to prove but to improve" to the teaching and learning process can then be described that: 1) The context is the condition/situation environment that affects both the poor teaching and learning process that occurred; 2) Input (means/capital/materials and strategic plan that have been determined in teaching and learning process, 3) process (implementation of teaching and learning process); 4) product: learning outcomes (level of knowledge, understanding, behavioral changes that occur). This model tries to see the performance of the learning process from various dimensions to arrive at the final conclusion about the quality of the learning process.

\section{B.CONCEPT FRAMEWORK}

\begin{tabular}{|c|c|c|c|}
\hline $\begin{array}{l}\text { Aspect of } \\
\text { study }\end{array}$ & $\begin{array}{l}\text { Dimen- } \\
\text { tion }\end{array}$ & $\begin{array}{l}\text { Measured/ } \\
\text { Observed } \\
\text { Variable }\end{array}$ & Scale \\
\hline $\begin{array}{l}\text { Sosiodem } \\
\text { ographic }\end{array}$ & Gender & $\begin{array}{l}\text { Male and } \\
\text { female }\end{array}$ & Nominal \\
\hline $\begin{array}{l}\text { Teaching } \\
\text {-learning } \\
\text { process }\end{array}$ & $\begin{array}{l}\text { Accounta } \\
\text { bility }\end{array}$ & $\begin{array}{l}\text { 1. The course } \\
\text { has an MBPP } \\
\text { / SAP } \\
\text { delivered to } \\
\text { the student at } \\
\text { the beginning } \\
\text { of the course. } \\
\text { 2. The course } \\
\text { has a } \\
\text { procedure for } \\
\text { evaluation of } \\
\text { learning } \\
\text { outcomes } \\
\text { agreed at the } \\
\text { beginning of } \\
\text { the lecture. } \\
\text { 3. The course } \\
\text { has a final } \\
\text { scoring } \\
\text { system } \\
\text { delivered at } \\
\text { the beginning } \\
\text { of the course. }\end{array}$ & Interval \\
\hline
\end{tabular}




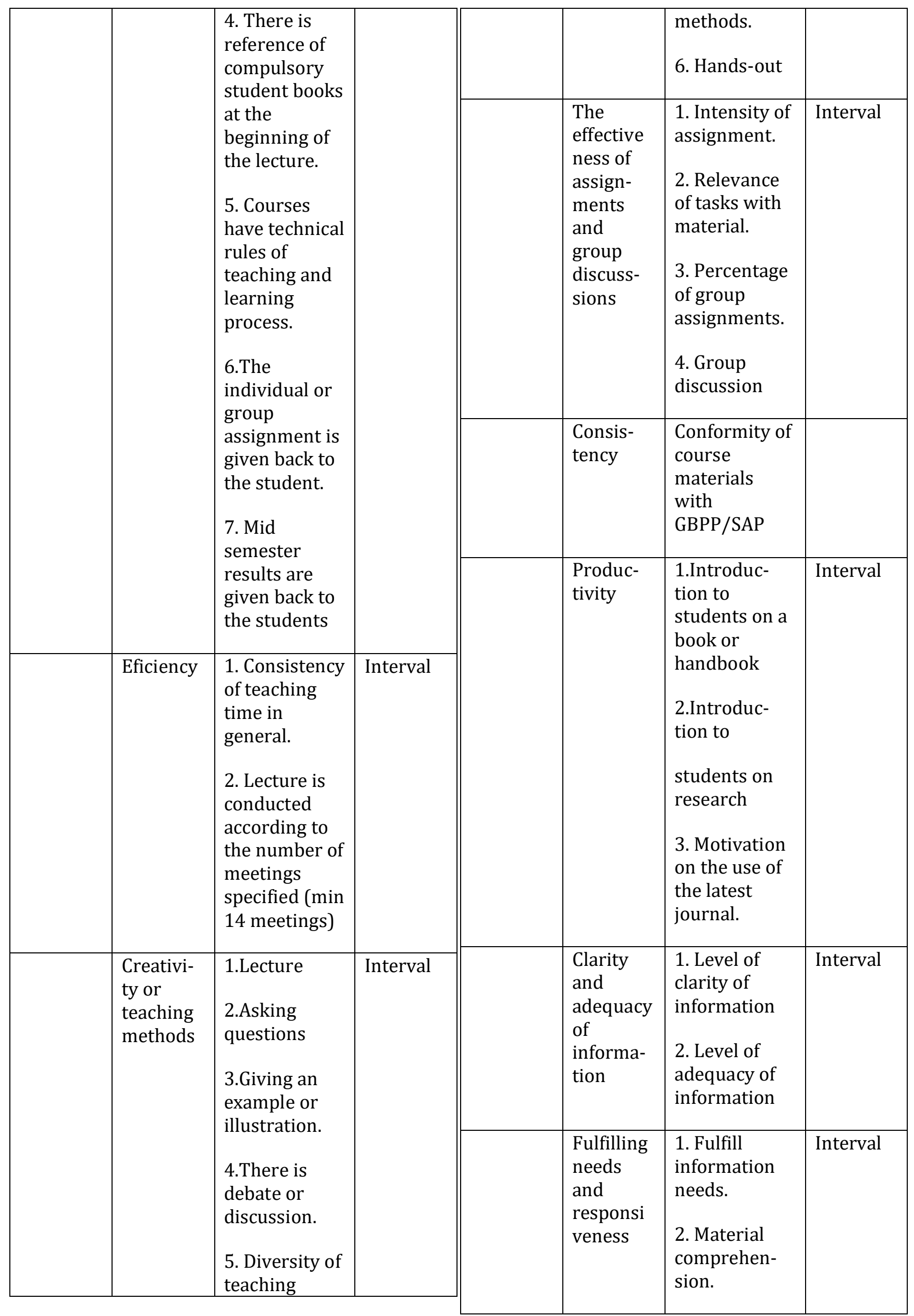




\begin{tabular}{|l|l|l|l|}
\hline & & $\begin{array}{l}\text { 3.Conveni- } \\
\text { ence to } \\
\text { inquire. }\end{array}$ & \\
\hline & $\begin{array}{l}\text { Level of } \\
\text { satisfac- } \\
\text { tion }\end{array}$ & $\begin{array}{l}\text { Level of } \\
\text { satisfaction }\end{array}$ & Interval \\
\hline
\end{tabular}

\section{RESEARCH METHODS}

To get an objective and measurable picture of the quality of the learning process that takes place in USU, the quantitative descriptive method is used. The population is a student of USU grade 2014, 2015, 2016 and new graduated alumni, who come from non-exact faculty namely; Faculty of Social namely; Faculty of Economics and Business, Faculty of Law, Faculty of Cultural Sciences, and Faculty of Social and Political Sciences. The number is 45,155 people, using slovin formula and the fault tolerance limit of $4.75 \%$ then obtained a sample of 220 people. These samples are evenly distributed across the four faculties using the randomsampel and accidental samples. Based on gender of male respondents as much as 38.2 percent and female 61.8 percent. Data collection is done through structured interviews, questionnaires, and secondary data.

\section{RESULTS AND DISCUSSIONS}

A: Accountability of Teaching-Learning Process

\section{Chart 1}

The course has a GBPP / SAP delivered to the student at the beginning of the course

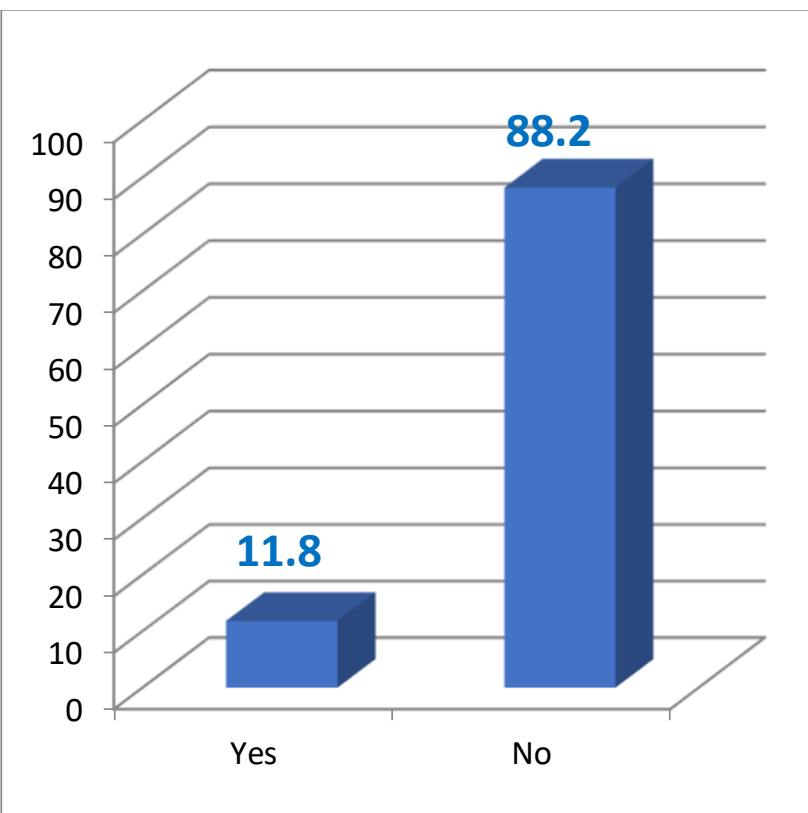

Souce: P71/FC6

The above data indicates a condition of concern. This is because the certified lecturers at USU rarely have and share the GBPP / SAP to the students. From the data it is known that only 11.8 percent of USU-certified lecturers own and distribute GBPP / SAP to students.

GBPP / SAP should be distributed to students at the beginning of each semester. GBPP which contains learning materials can be a student guide in following the lectures for one semester. GBPP / SAP is also a guide as well as controlling lecturers in composing lecture materials. Tujuaanya is a picture of learning achievement can be monitored by the lecturer concerned. 


\section{Chart 2}

The course has a procedure for evaluation of learning outcomes agreed upon at the beginning of the lecture

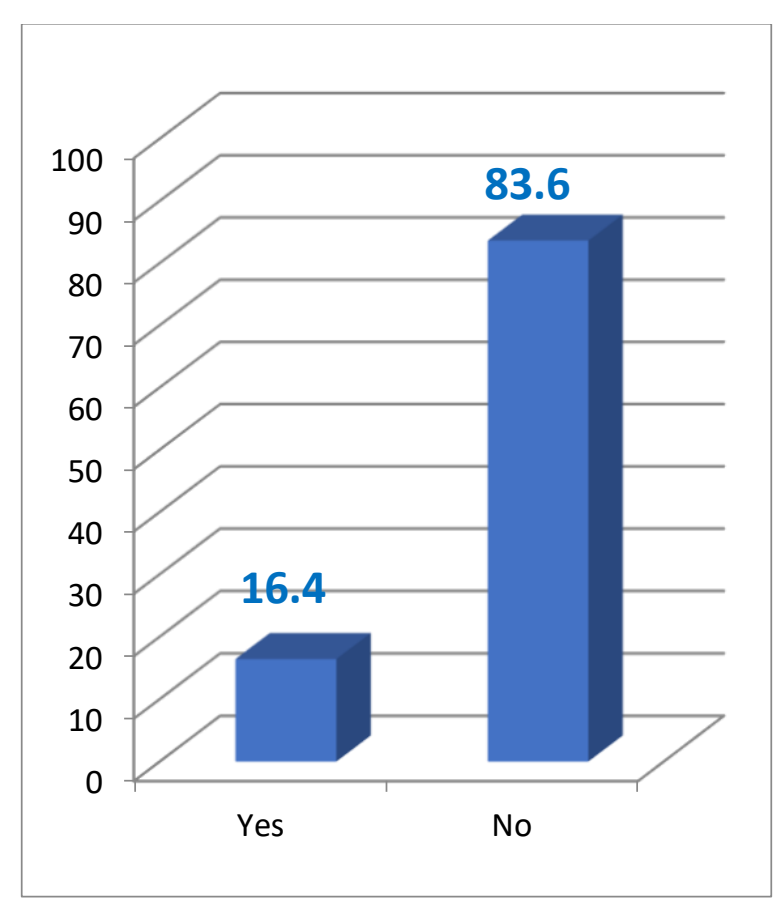

Source: P72/FC7

Each course should have a method or method of evaluation of learning outcomes. The lecturer should submit a review mechanism for each evaluation category. For example tasks, the general standards used are questions of originality, citation procedures, and which sources may be used as references.

From the above data can be seen that the percentage of certified lecturers who have the evaluation of teaching and learning is very low. The percentage of lecturers who submitted the procedures for evaluating the results of teaching and learning to students is only 16.4 percent.

\section{Chart 3}

The course has a final assessment system delivered at the beginning of the course

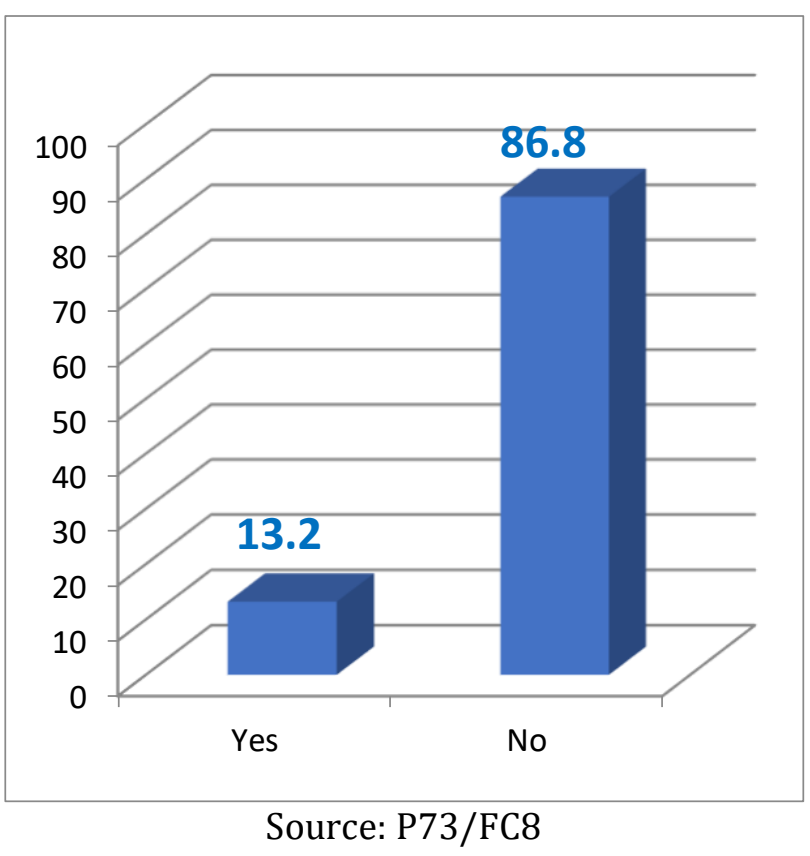

The final assessment system of learning outcomes that generally apply in the standard of education are quiz, duty, mid semester, and semester exam. In the practice of lectures, generally the percentage of the assessment is, 10 percent quiz, 20 percent duties, mid-semester 30 percent, and 40 percent semester exam.

At the beginning of the meeting, lecturers are obliged to submit evaluation procedures to all class participants. The goal is, so that the class participants have information about what should be met to get the maximum value. Students should also be given an opportunity to file an objection if the appraisal points are deemed inconsistent with the tasks that the student has undertaken.

From the above data can be seen that the percentage of lecturers according to the respondents who delivered the final assessment system is very low. A total of 86.8 percent of respondents stated that certified lecturers did not convey to the students the final scoring system at the beginning of the lecture. 


\section{Chart 4}

There are references to compulsory student books at the beginning of the lecture

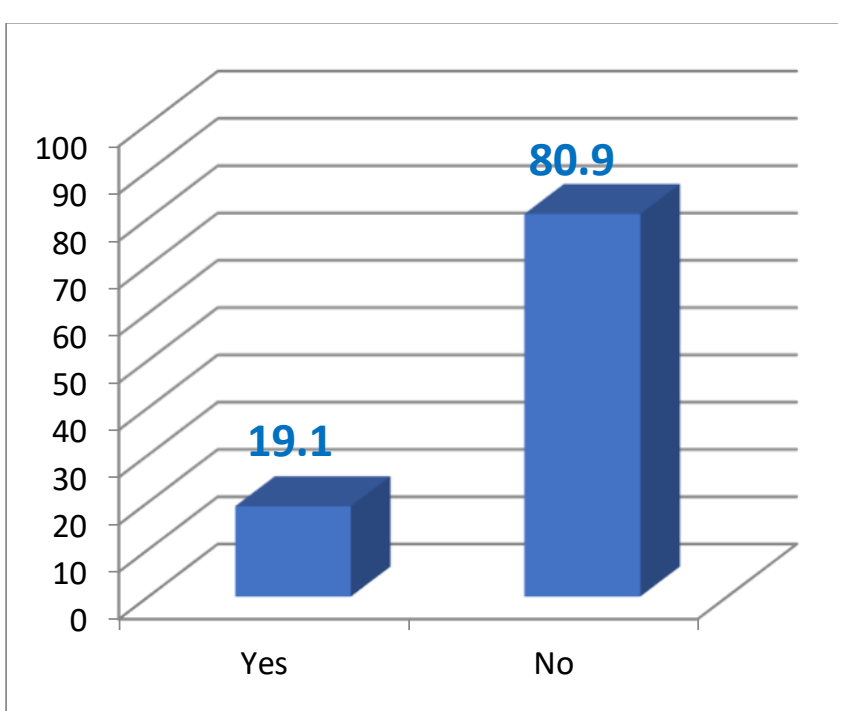

Souce: P74/FC9

The course references consist of compulsory books that guide the learning process. Lecturers are required to provide references on the title of the book relating to learning materials. Based on the data above can be seen that the reference lectures have not become the attention of certified lecturers at USU.

The reference book is a scientific paper whose substantive discussion focuses on one area of science. Each course generally focuses on a specific study, and must have a reference book. The use of reference books can help class participants to further deepen the scientific study of material presented. The use of reference books can also help to create an active discussion between lecturers and class participants, where the students do not merely rely on learning information from lecturers, but also from reference books that have been recognized in scientific studies.

Apparently only $19.1 \%$ of respondents stated that certified lecturers who provide reference lectures during the learning process. While the majority of respondents ie 80.9 percent stated that certified lecturers do not provide reference lectures during the learning process.

\section{Chart 5}

The course has a technical rule of teaching and learning process

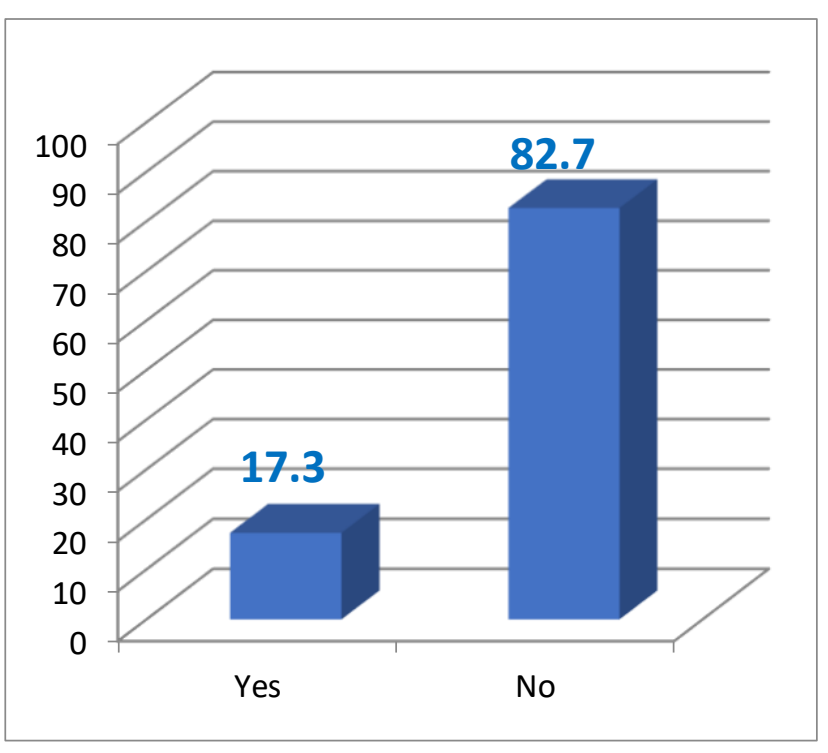

Souce: P75/FC10

The learning process requires instructional technical rules that need to be agreed with the class participants. These technical rules such as the rules on tolerance of delay for both lecturers and students, the mechanism of task collection, to dress code. This technical rule guides all class participants during the learning process. The existence of technical rules of lectures will help the learning process run orderly and regularly. Order in the learning process will help create a good academic atmosphere.

From the above data it can be seen that most of the respondents stated that certified lecturers generally do not have and submit technical rules during the learning process. Only 17.3 percent of respondents confirmed that certified lecturers possess and submit technical lecture rules. 
Chart 6

The individual or group assignment is given back to the student.

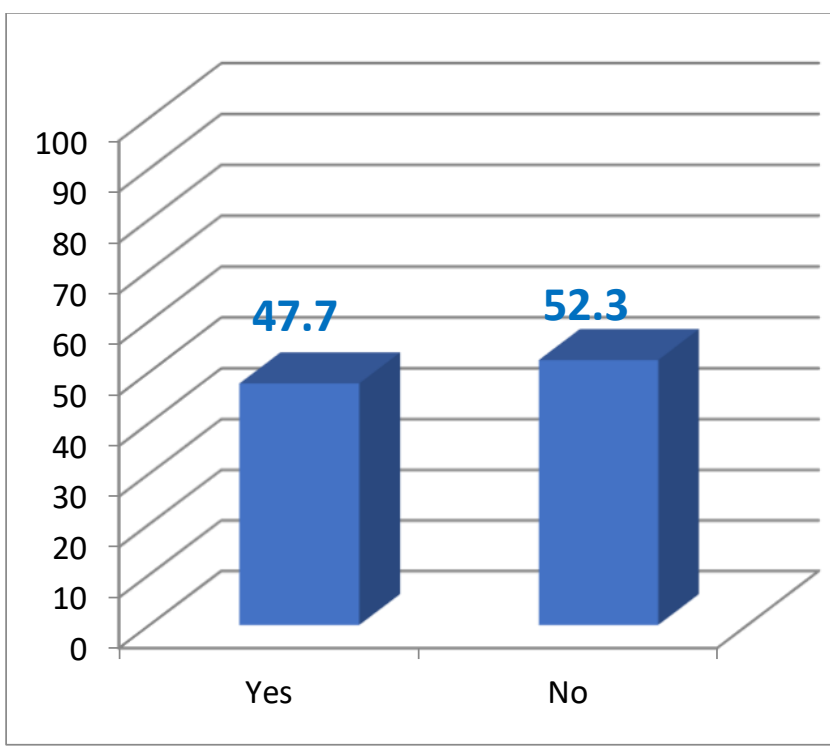

Source: P76/FC11

Provision of tasks during the learning process is one important part to improve the knowledge and understanding of class participants about the material presented. Commonly assigned task forms are paper, project work, resume, and others.

Refunds of corrected tasks are important to students in order for students and lecturers to have advanced discussions on issues that are important or inappropriate in the student's assignment. Students may file an objection and confirm if any assessment category is deemed inappropriate.

Implementation of the mechanism of the return of tasks still can not be said to be ideal. This is due to the high respondents who stated that certified lecturers did not return the class assignment to the participants. The data show that 47.7 percent of respondents in USU state that a certified lecturer returns a college assignment. While the percentage of respondents who stated that the lecturer did not return the lecture duties to the students reached more than 50 percent ie 52.3 percent.

\section{Chart 7}

Mid semester results are given back to the students

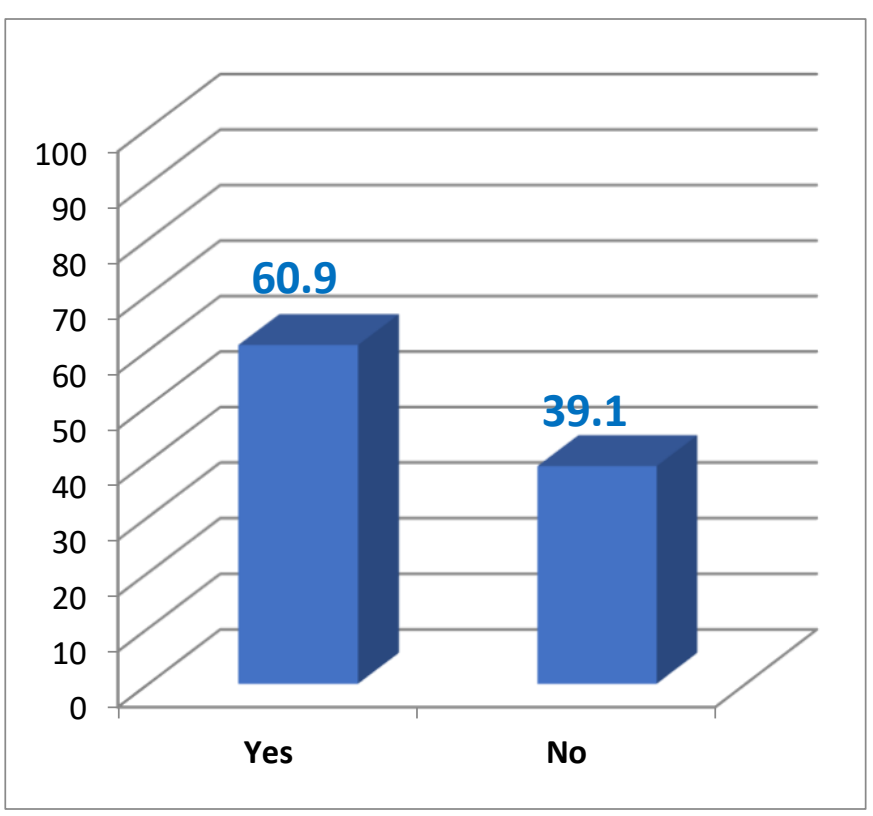

Source: P77/FC12

From the above data it can be seen that the respondents stated that quite a lot of certified lecturers who returned the mid task to the class participants. The above chart shows that as many as 60.9 percent of respondents stated that the lecturers returned mid-return to the students. While the percentage of respondents who stated that certified lecturers did not return the results of mid-semester to class participants about 39.1 percent.

Return of the mid semester result is part of the transparency of the learning process. With the mid duty return provides an opportunity for students to provide feed back on the assessment given by the lecturer concerned. Feedback can be either a critique or a correction of a lecturer's assessment if there is an error in the midsemester assessment. Lecturers should provide discussion opportunities for complaints or feedback from class participants. With such mechanism, the lecturer's assessment is clear and accountable. 
Chart 8

Teaching materials are associated with relevant research results

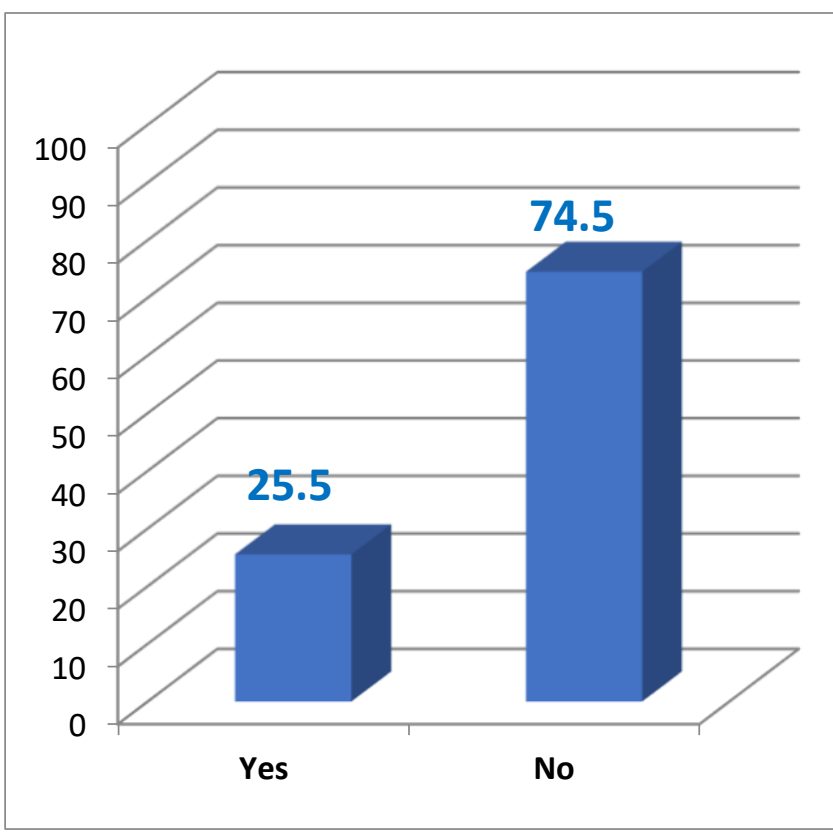

Source: P78/FC13

The preparation of teaching materials should always keep up with the times and knowledge. The development of the times must be followed by the ability of scientific studies to anticipate and follow the new phenomena that arise from the development of the times. The ability of the learning process to keep up with the times will make it easier for college graduates to be absorbed by the job market.

One medium that can be used to update teaching materials is recent research related to lecture materials. The above data shows that the percentage of lecturers who associate teaching materials with the latest research is categorized as low. This can be seen from the percentage that only reached 25.5 percent.

This is of course quite alarming, since class participants do not get the latest knowledge about the material presented. In the social sciences, the development of science is always changing. Developed theories always get criticism and revision of the current study, therefore there needs to be updated information to be submitted to the class participants.

\section{Chart 9}

Lectures using new media (journal links, websites, social media, email)

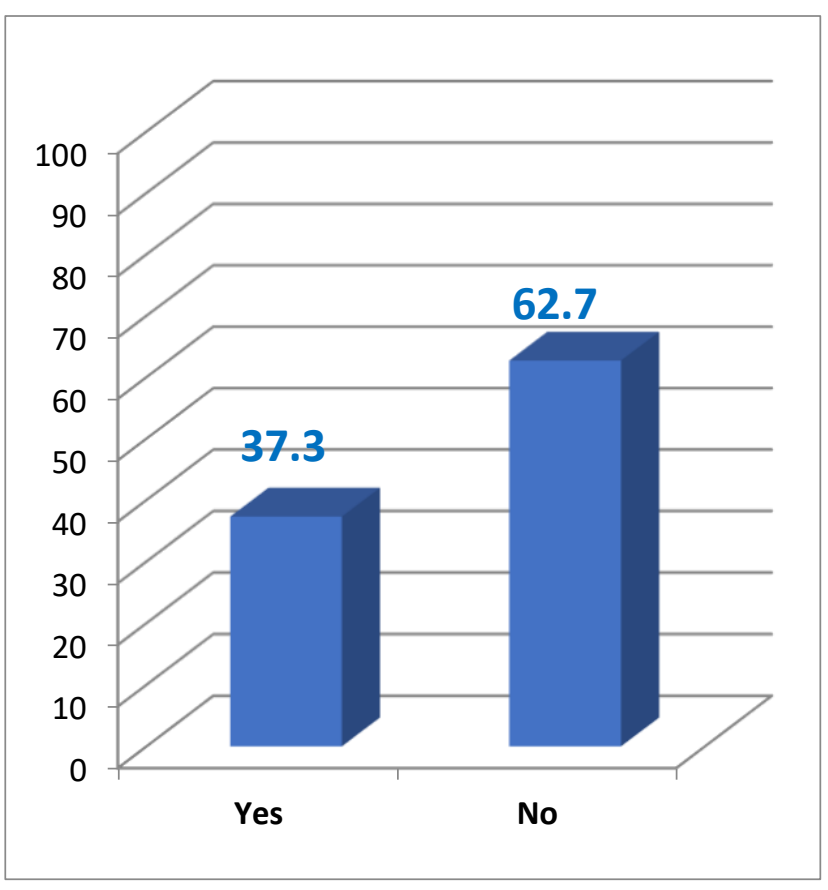

Source: P79/FC14

The development of communication technology has a major role in the change of learning methods. The existence of the internet has expanded the method of learning that is now not merely relying on the material of the lecturer concerned. The Internet makes access to journals much easier. Coupled with many open source journals that make its users do not have to pay for information. Likewise with teaching materials and tasks that are now paperless, so that lecturers can use the medium of email to collect tasks.

Implemention of communication technology has not been applied optimally there are two universities. This can be seen from the Chart above which shows that the respondents who stated that the certified lecturer using the new media percentage is only 37.3 percent, while the rest of which is 62.7 percent said 'no'.

One reason for the low access of lecturers to new media is the age factor of lecturers, where more elderly lecturers. This is coupled with the recruitment process in PTN which is not easy, so there is a gap that is quite far between the lecturers and younger lecturers. 
B : Accountability of Teaching Lecturer

Chart 10

Consistency of teaching time in general

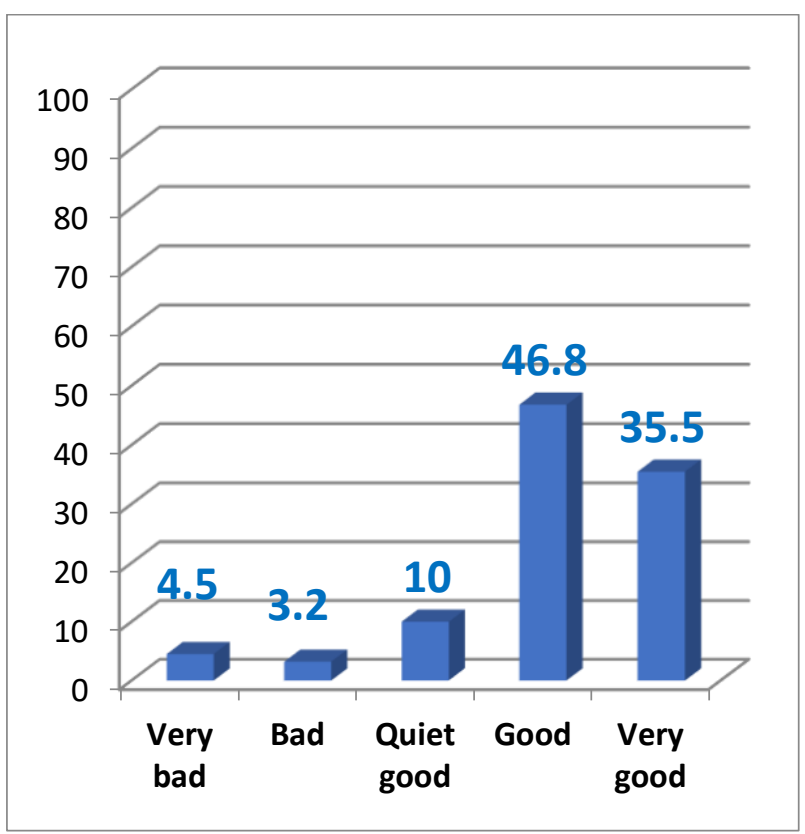

Source: P81/FC15

Consistency of teaching time is related to the accuracy and consistency of lecturers' time in taking the time during the teaching and learning process. From the above data can be seen that the consistency of teaching time certified lecturers have been very good. A total of 46.8 percent of respondents stated the consistency of teaching time certified lecturers into good category, and 35.5 percent are in very good category.

The consistency of teaching is related to the discipline of the lecturer in taking time face to face with the students in the class. A face-toface meeting is the right of the student as a class participant to gain exposure from the lecturer on the theme presented in the lecture material.

\section{Chart 11}

Lectures are conducted according to the number of meetings specified (minimum 14 meetings)

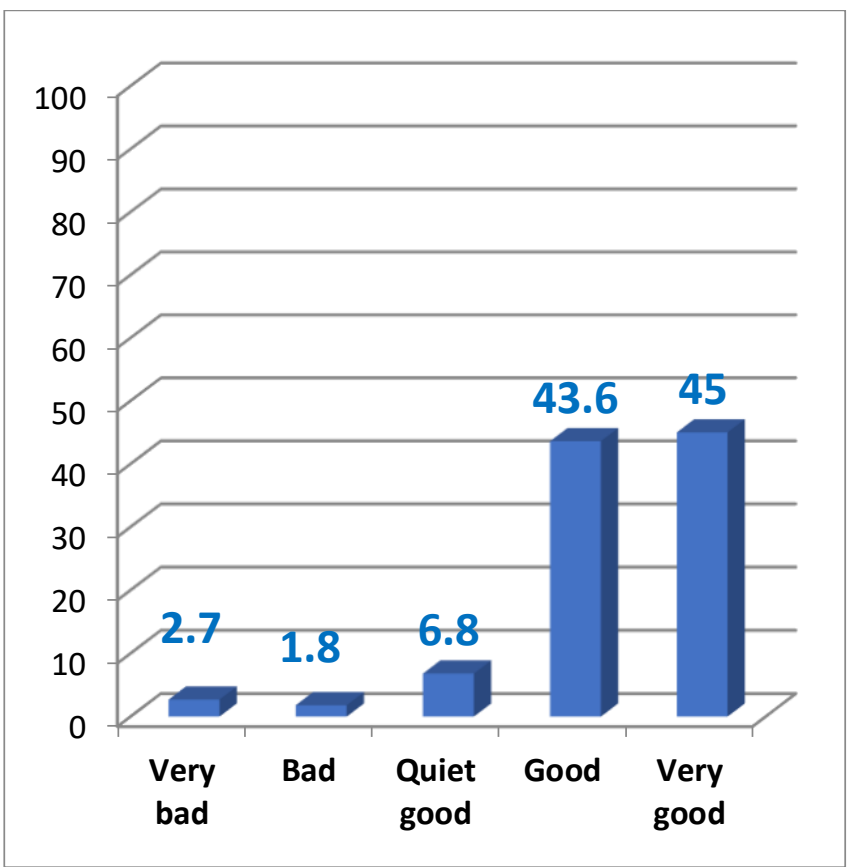

Source: P82/FC16

In general, lectures are held in 14-16 meetings, consisting of 14 face-to-face meetings, and 2 meetings for mid and final exam of the semester. The consistency of lecturing is very good.

Lecturers prepare lecture material for each meeting in GBPP / SAP which will present the themes of what will be discussed during one semester of lecture. In the 14 planned meetings, the lecturer concerned can arrange the learning method with various variations according to the learning objectives.

From the respondents it is known that the quality of the number of lectures dominant at the level of Good, and Very Good. 


\section{C : Creativity of Teaching Methods}

Chart 12

The teaching method used is discourse

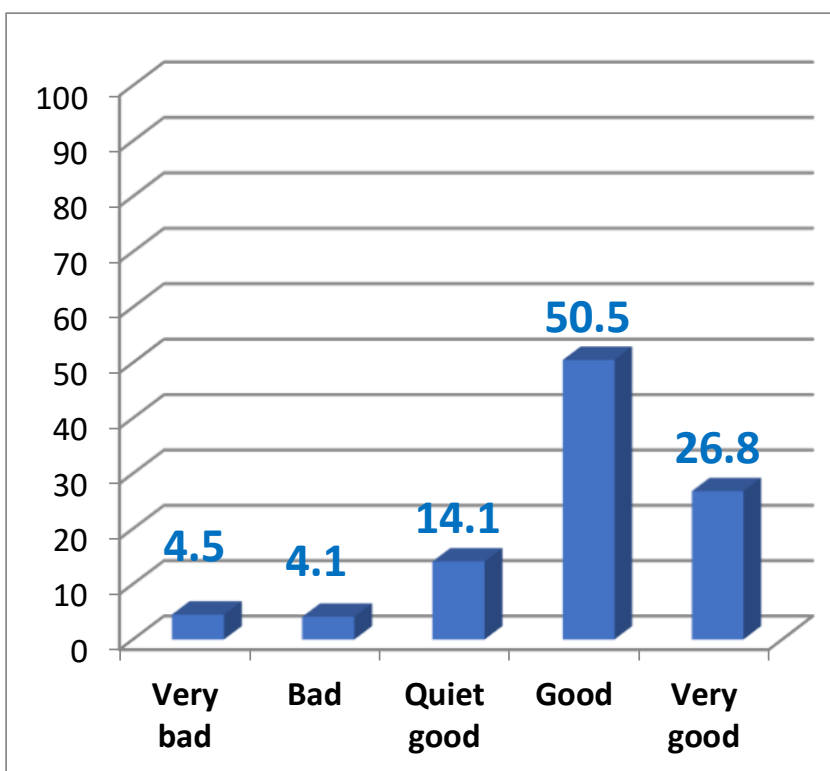

Source: P831/FC16

The discourse method is a common method used in lecturing. In this method, it must be admitted that interaction will be more minimal because the process is monologue process.

This method requires the good ability of the lecturer to deliver the material in an interesting way. However, in practice the use of discourse methods can be boring. Especially if the lecturer concerned failed to 'greet' all the class participants. Not infrequently class participants sleepy, or even chat with fellow class participants.

The results of this study indicate that the discourse method used by certified lecturers generally takes place well. Most of the lecturers certified according to the respondents are in the category of Good and Very Good. As many as 50.5 percent of respondents answered that the discourse method used by lecturers included in the category of Good, and total of 26.8 percent stated Very Good. But there are a few who choose the option Quiet Good, Bad, or Very Bad.
Chart 13

Asking question

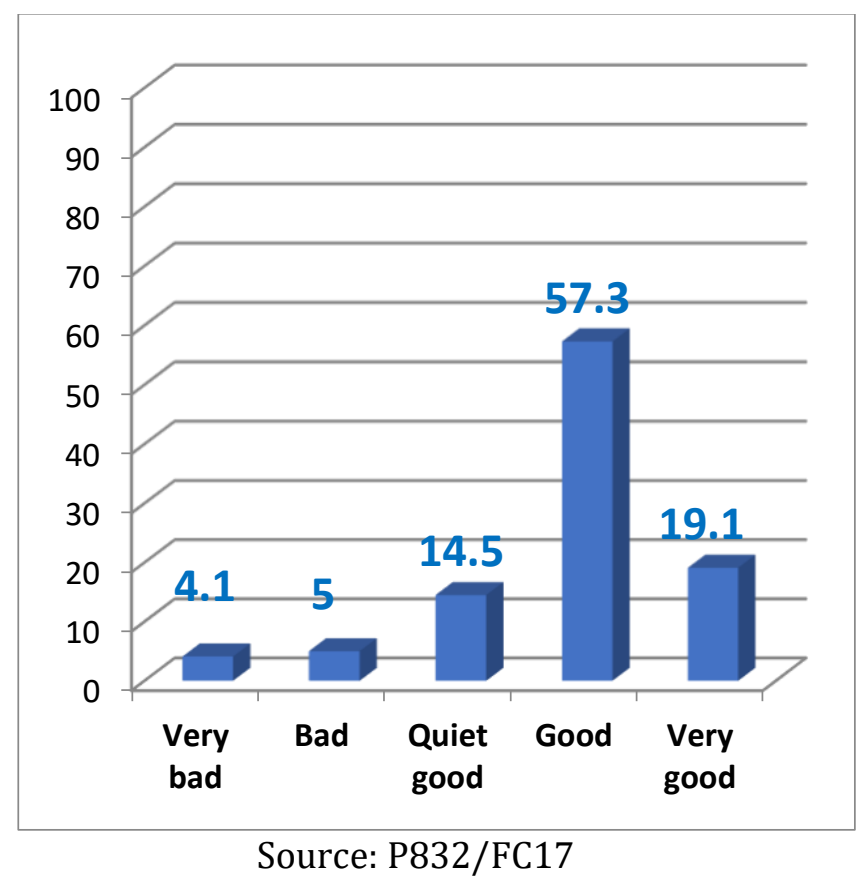

This variable emphasizes the question of whether the lecturer opens opportunities for students to ask questions during the learning process. The more often the lecturer provides opportunities for students to ask questions, the better the assessment.

The chart above shows that certified lecturers provide a good opportunity for classroom students to ask questions. As many as 57.3 percent of respondents chose the Good option, and 19.1 percent answered Very Good.

This data also shows that as many as 14.5 percent of respondents stated Quiet Good. For Bad and Very Bad answer options the percentage is very low, between 0.5 to 5 percent. 
Chart 14

Giving examples/illustrations

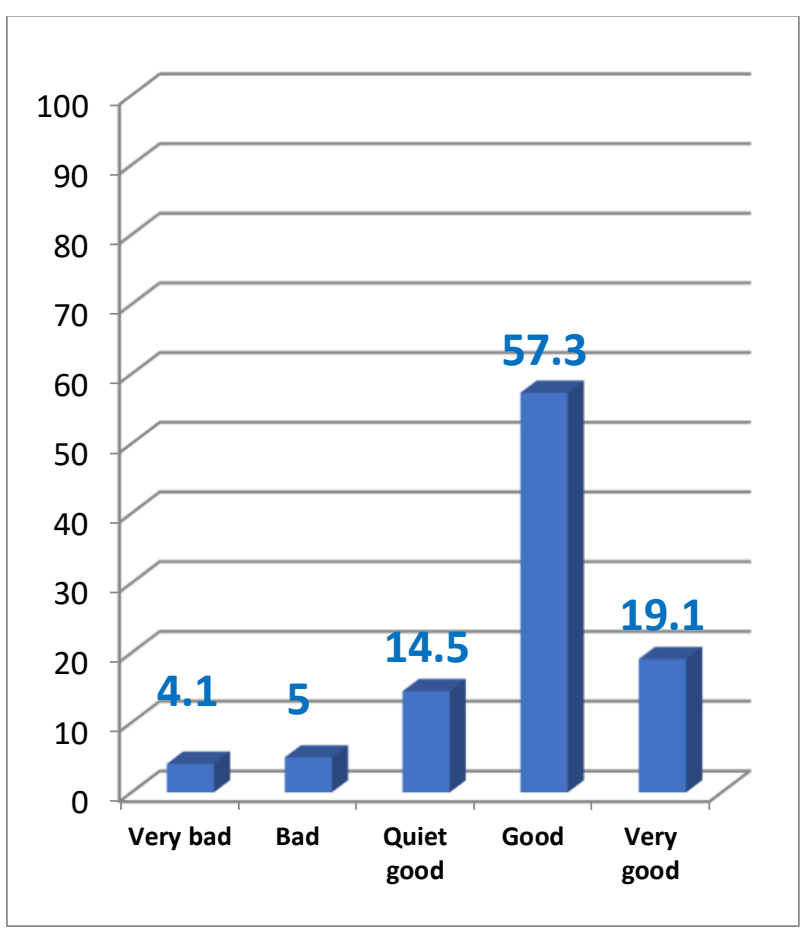

Source: P833/FC18

Illustrations/examples related to lecture materials will help students to better understand the lecture material. Lecturers should be able to provide examples close to everyday life. This variable emphasizes whether the illustrations used by the lecturers are interesting and have conformity to the material being taught. Illustrations can be narratives delivered by lecturers orally or through graphic help. Illustrative materials can be obtained from materials available on the internet, books, illustrations made by the lecturers themselves, as well as other sources.

From the data of this study it is known that certified lecturers are considered able to provide illustrations/examples of interest and easy to understand by students. As many as 57.3 percent of respondents stated good, and 19.1 states Very Good.
Chart 15

Make discussion/debate

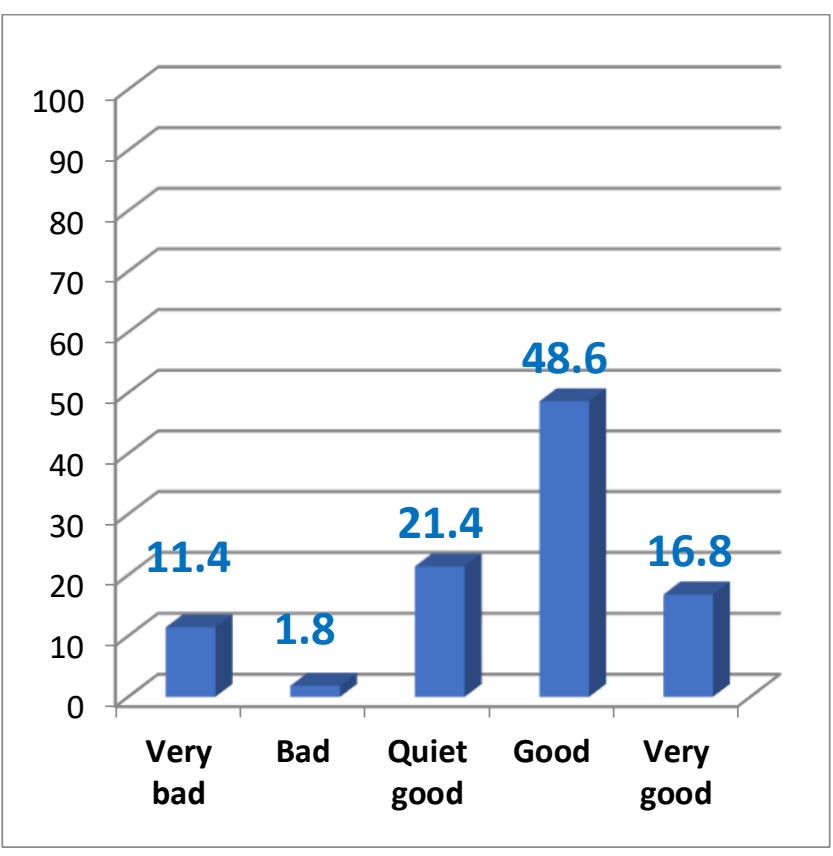

Source: P834/FC19

Debates can help students to practice analytical skills and argue. Of course the argument in question is scientific argumentation. In the learning process lecturers must provide an opportunity for class participants to provide scientific arguments related to the teaching materials delivered.

In the study of social science is not denied the debate about the theory, policy, or social phenomenon of society. The learning process should provide opportunities for discussion or debate about the phenomenon concerned. However, such discussions or debates must remain clear on the basis of scholarship so that the ongoing debate is not a mere 'coachman' debate. All parties involved in the debate should be able to accept any consequences including if their opinions are broken by others. The debate should be able to accommodate different views, although it will ultimately lead to the term "Agree to Not Agree".

The research findings show that certified lecturers have provided an opportunity for students to argue in discussions. The percentage who answered the Good category reached 48.6 percent, and 16.8 percent of respondents answered Very Good. 
Chart 17

Chart 16

Giving group assignment

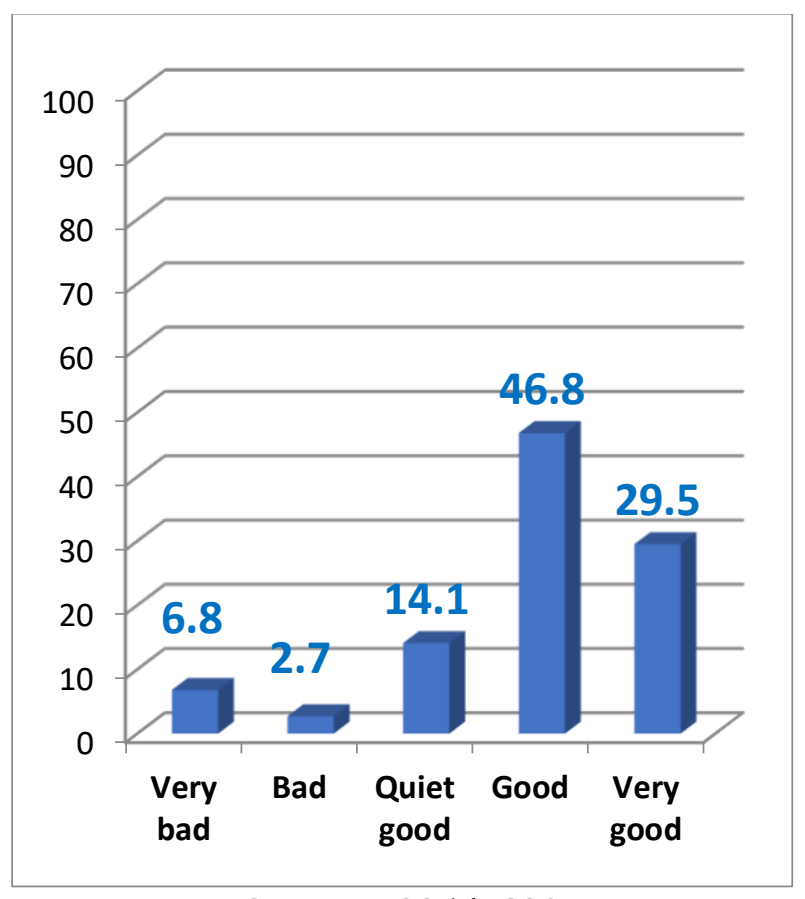

Source: P835/FC20

The chart of the above results shows that the percentage that chose the Very Bad or Bad answer option is very low. Only 6.8 percent answered Very Bad, and 2.7 percent answered Bad.

This means that the mechanism of group assignment by certified lecturers has been very good. Assumptions related to the task is that the more tasks are given, the better the quality of the learning process is carried out.
Group assignment presentation

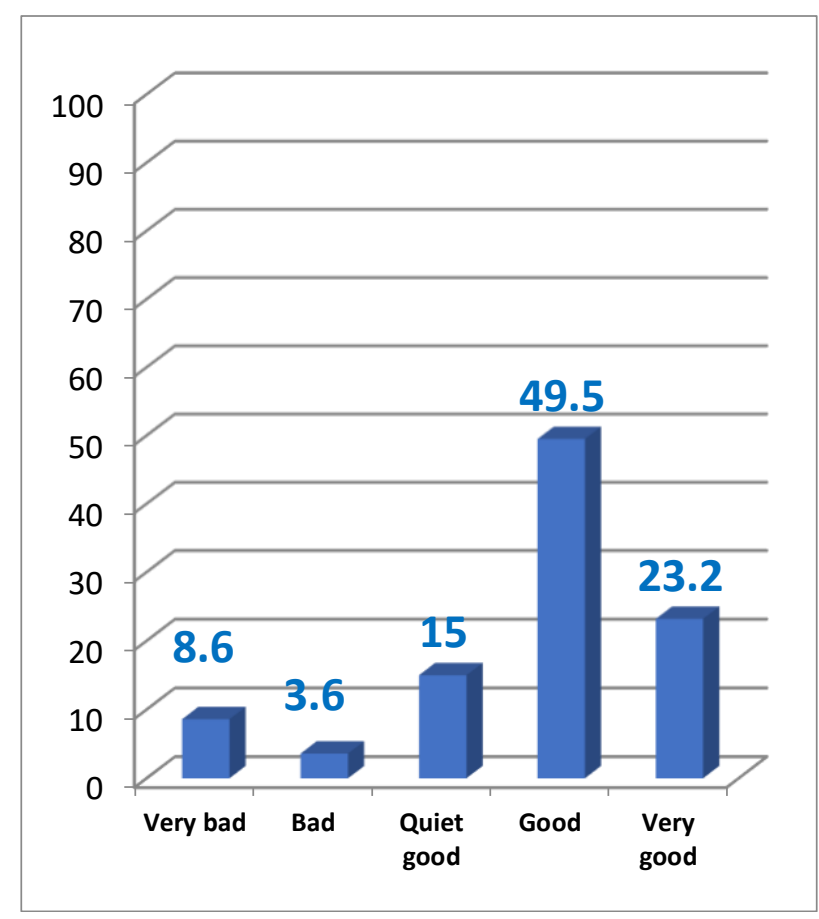

Source: P836/FC21

Presentation is an important part of the learning process that aims to train the communication skills of class participants. In the presentation, the presenter in this case is a student of class participants dituntuk to explain the study results in a timely manner and were able to convey the communicative to the audience.

Presentations are an important part of the skills element. The skills in question are the skills to sort out the material about to be presented in a brief but effective, speech, and the ability to provide images / graphics that can attract attention. Lecturer in this case not only serves to listen to the presentation of class participants, but also the correct method and manner of presentation used by the presenter.

Data show that the majority of participants are satisfied with the implementation of a group presentation directed by lecturers certified. The percentage of the Good is 49.5 percent, and 23.2 percent answered Very Good. 
Chart 18

Group discussion

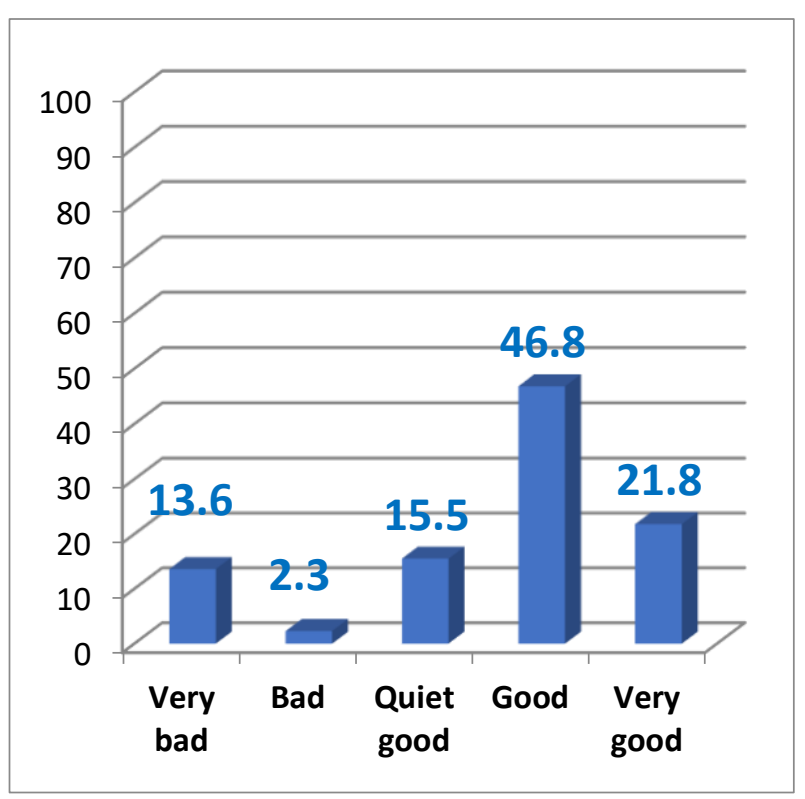

Source: P837/FC22

One of the most effective learning methods is Group Discussion. Group discussion is an important part of learning so that class participants can share knowledge related to learning materials. Through the group discussion forum the class participants can exchange ideas about what is not understood about the subject matter. Group discussions may also expand the subject of discussion that may be tangent to the course material.

The mechanism of group discussion can be said to be good. This can be seen from the percentage of ratings that ranges from 46.8 percent for the Good option, and the Very Good option of 21.8 percent. But this is what needs to be a concern for USU because the percentage of respondents who answered Very Bad is rather high, ie as much as 13.6 percent.
Chart 19

Diversity of teaching methods in one meeting

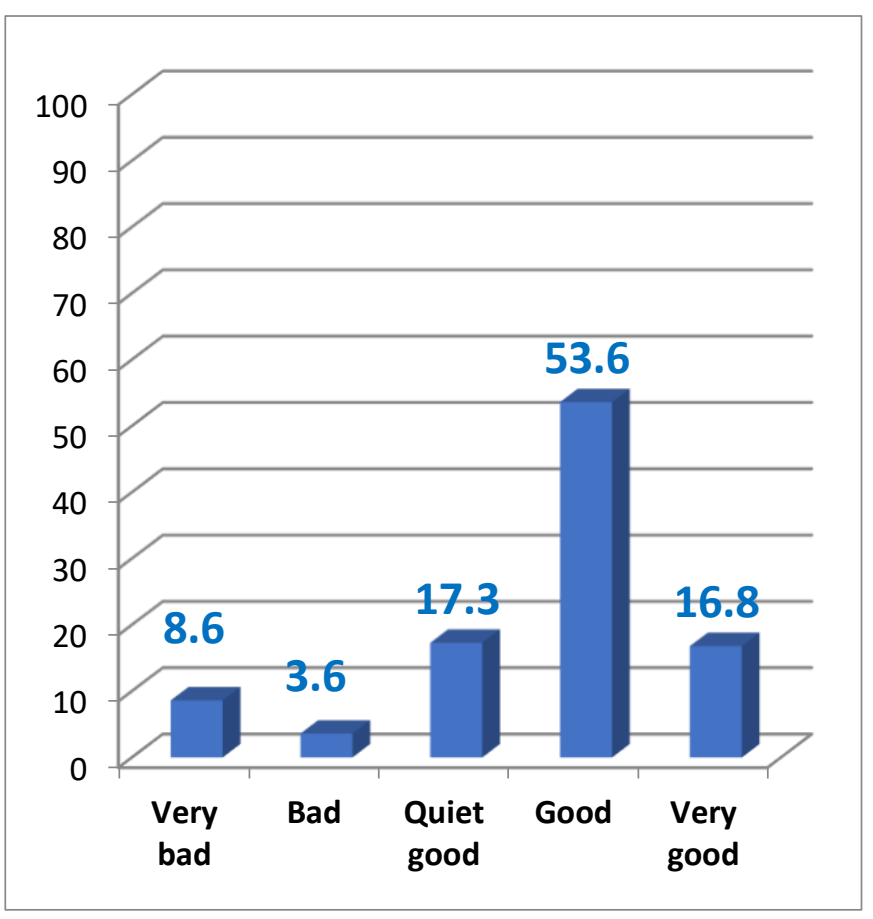

Source: P84/FC23

Some of the learning methods commonly used in the learning process are lectures, discussions, seminars, role plays, and so on. In the learning process that lasts for one semester, the lecturer should vary some learning methods. The goal is to avoid student saturation, as well as to explore the different knowledge and skills of each learning method.

Percentage of respondents who answered that the diversity of teaching methods used by certified lecturers can be said to be good. The percentage who answered Good as much as 53.6 percent, and 16.8 percent who stated Very Good. 
Chart 20

The presence of handouts at each meeting

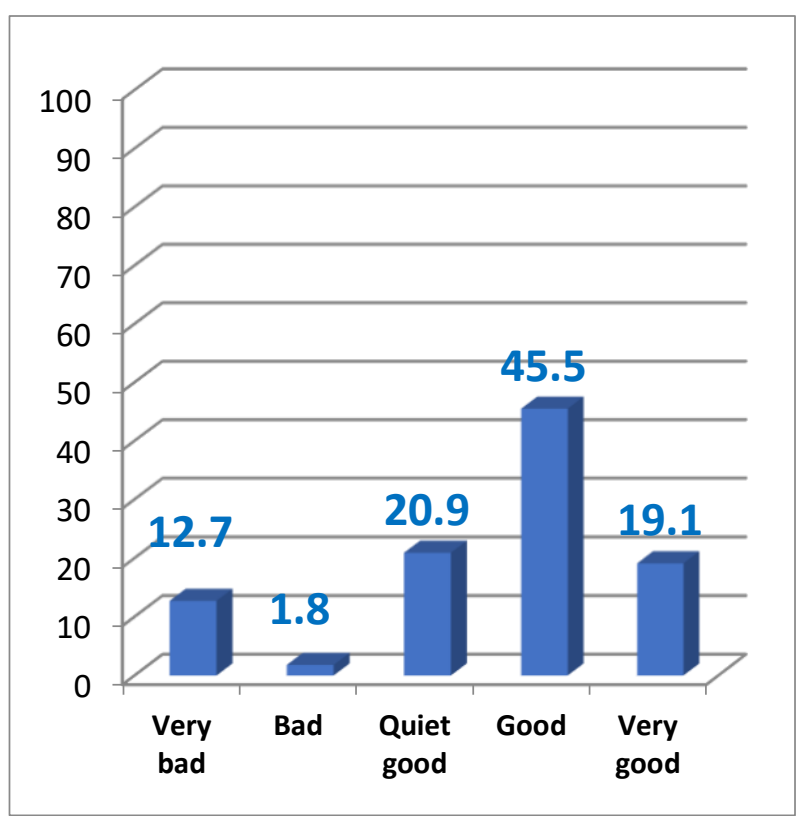

Source: P85/FC24

Based on the above data shows that most certified lecturers give handouts to students who are participants in the class. As many as 45.5 percent of respondents answered Good, and 19.1 percent answered Very Good.

Handout is a lecture material delivered by lecturers in lecturing process. Can be in hardcopy (paper), or soft copy like a power point slide. Distribution of class lecture handouts to class participants will facilitate students to understand the lecture material delivered. The presence of handouts also shows the readiness of lecturers in preparing the learning materials.
D: Effectiveness of Assignment and Group Discussion

Chart 21

Intensity of giving assignment

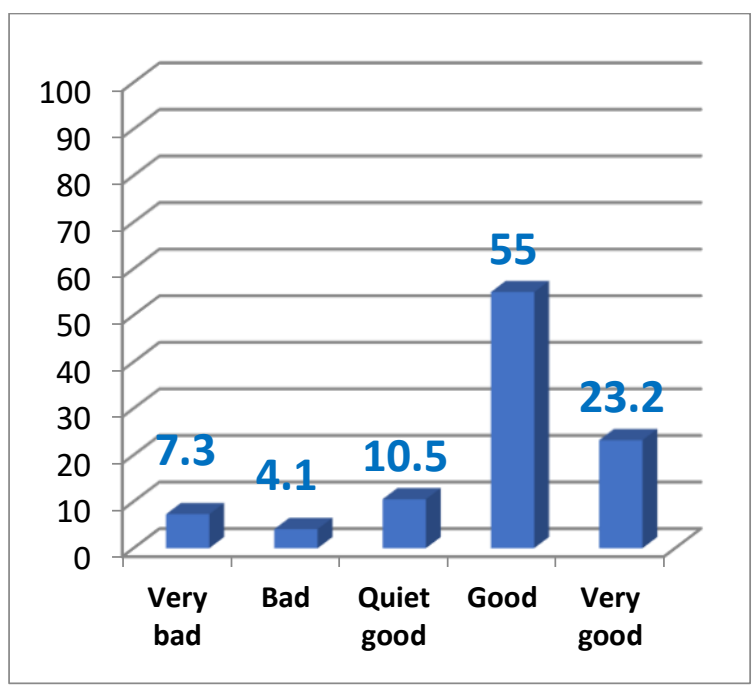

Source: P86/FC25

The intensity of assignment will also influence the ability of class participants to gain knowledge of the course material presented. The assumption is, the more tasks the better the knowledge the students get. By doing the task, students can deepen their analytical skills, read more references, and understand learning materials more focused.

The data of this study indicate that the intensity of assignment by certified lecturers has been running very well. As many as 55 percent of respondents stated that the intensity of assignment included in the Good category, and 23.2 percent others stated Very Good. 
Chart 22

The assignment is relevant to the subject matter being taught

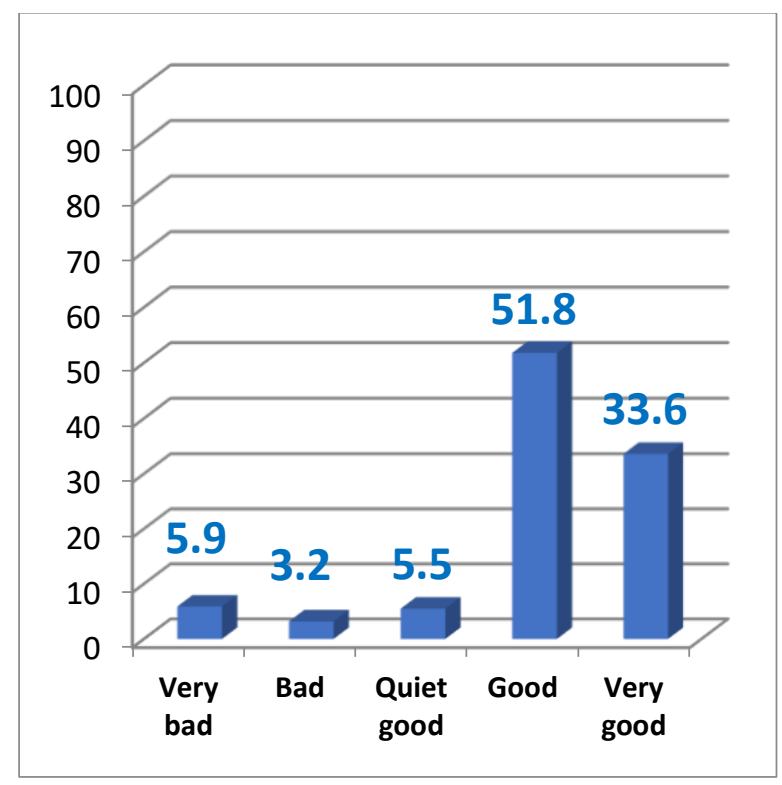

Source: P87/FC26

As many as 51.8 percent of respondents stated Good, that certified lecturers have assigned tasks relevant to the course material presented, and 33.6 others even stated Very Good.

The relevance of the tasks with the lecture material will help the students to understand and improve the knowledge related to the lecture material in question. The task can be paper, project, book resume or scientific journal. Making tasks will help students to have the knowledge and skills about writing with scientific standards, the design of power point design, to how to present the task in an interesting and easily understood by the audience.

In the examination of tasks, lecturers will emphasize on several things, namely technical writing (typo, grammar, citation procedures, etc.), analytical skills presented in the task, to the ability to read the latest reference is important as independent learning materials.

\section{E : Consistency}

Chart 23

Conformity of course materials at each meeting with GBPP / SAP

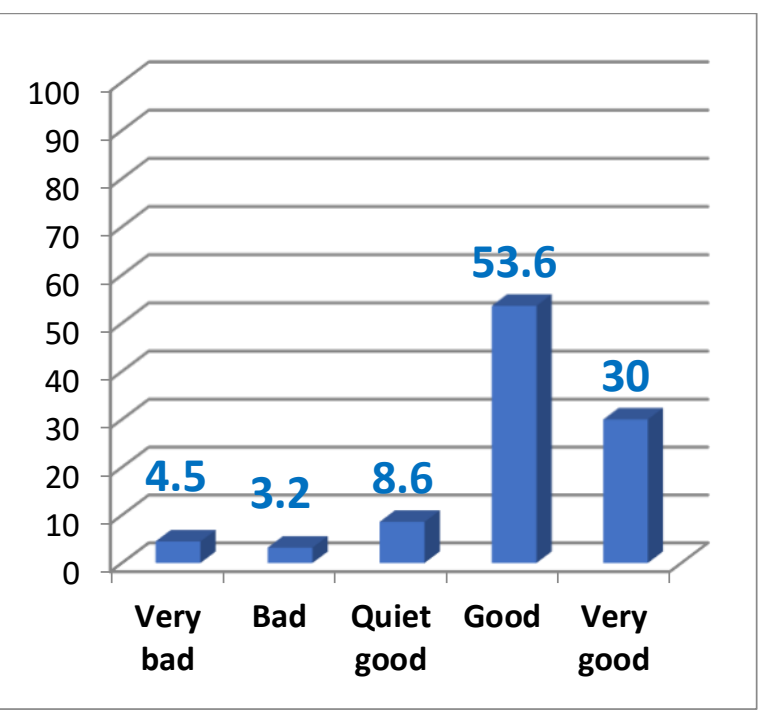

Source: P88/FC27

SAP/GBPP becomes the joint guide between lecturers and students to run and follow lectures. With the SAP/GBPP students are expected to have more time to find information in advance about the material to be delivered. The hope, the discussion process can take place more dynamically during the lecture. Dynamic lecturing process is characterized by a process of mutual discussion between lecturers and students, not just a monologue lecture.

Preparation of SAP/GBPP is not only a prerequisite for lecturers to teach well and quality, but also a form of lecturer accountability to institutions and students related to whether the lecture material given by the lecturer is in accordance with the teaching objectives set by the institution.

The results of this study indicate that the conformity of SAP/GBPP with the material presented is good. As many as 53.6 percent of respondents stated Good, and another 30 percent stated Very Good. 


\section{F : Productivity}

\section{Chart 24}

Student introduction to the latest book / handbook

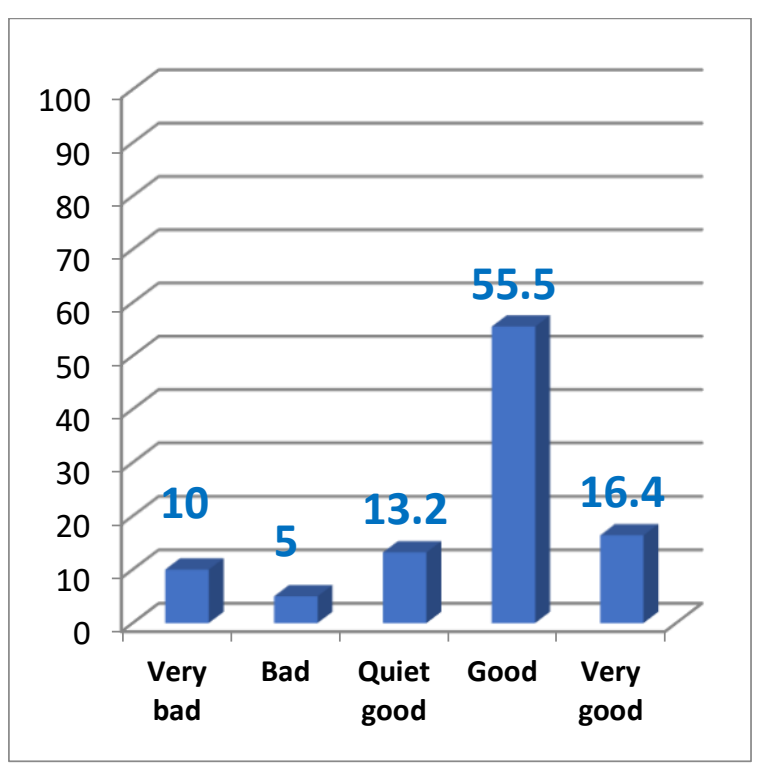

Source: P89/FC28

The development of knowledge, especially in social science continues to experience dynamic development. The dynamics of such knowledge can be seen from the dynamics of the learning books used in the academic process. Lecturers, in the information transfer process should introduce the class participants with the latest updates of the books.

Based on the above data, it can be seen that the implementation of this mechanism has been going well. The certified lecturers at both universities according to the respondents have introduced class participants in the latest handbook related to the field of science. The data show that 55.5 percent of respondents think Good, and 16.4 respondents stated Very Good.

Although in general the exercise is considered good but there are still 10 percent of respondents who answered Very Bad, and 5 percent who answered Bad.
Chart 25

Introduction of students on themes / topics that can be developed into research

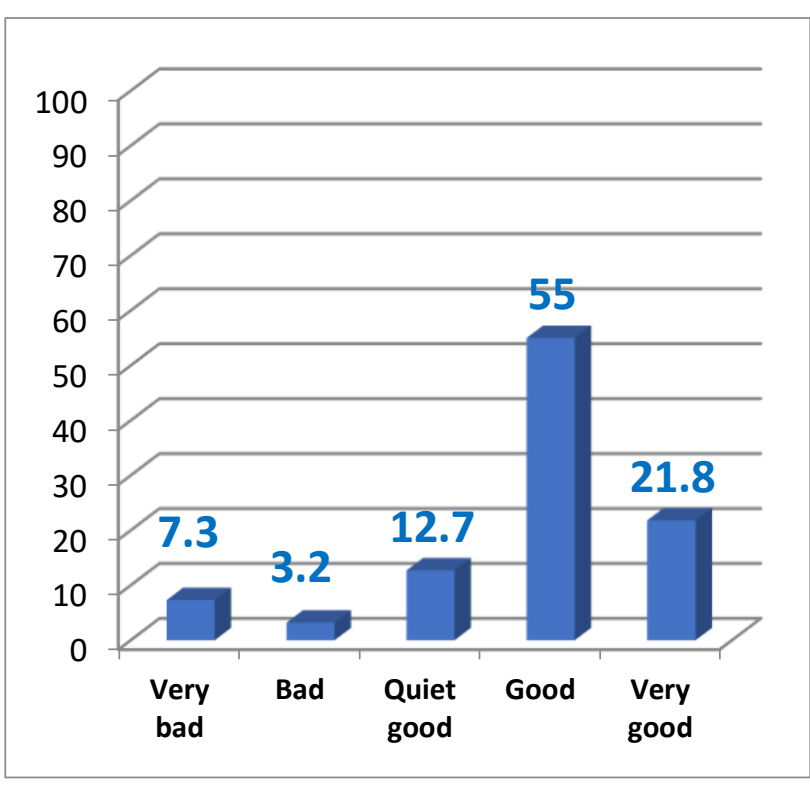

Source: P810/FC28

University as intellectual producer institutions are expected to contribute to the development of science, especially through academic research. Academic research becomes the entrance for the implementation and evaluation of development program policies. Therefore, lecturers should be able to inspire and motivate students to be able to analyze social problems in society through scientific research. In addition, to save themselves from college must go through the mechanism of writing thesis as the final project. Inspiration research problem this thesis can be prepared during the lecture in accordance with the interests and abilities of students.

Based on the above data is known that certified lecturers have the ability to inspire students to raise a theme or a particular topic as a subject of academic research. This can be seen from the percentage of respondents who answered Good as much as 55 percent, Very Good 21.8 percent. 
Chart 26

Giving motivation to use the latest journals

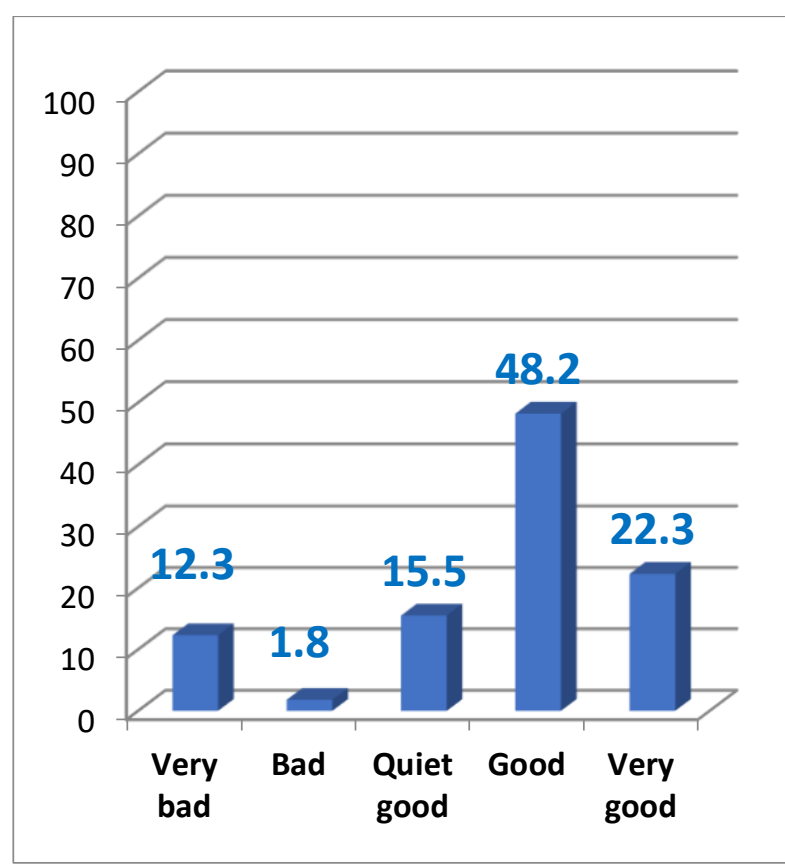

Source: P811/FC28

Journals are a medium for getting information on the latest studies in science. Access to journals can be obtained by subscription or through open source. Good access to journal links will help students better understand learning materials. We can find the latest research dynamics in scientific journals that have been recognized by the scientific community. Especially in journals that have been recognized with nationally accredited status and that have been indexed internationally.

Based on the above data it can be seen that as many as 48.2 percent of respondents stated Good, and 22.3 percent of respondents stated Very Good.

However, there are still 12.3 percent of respondents who answered Very Bad.

\section{G : Clarity and Information Sufficiency}

Chart 27

Clarity of information gained in each meeting

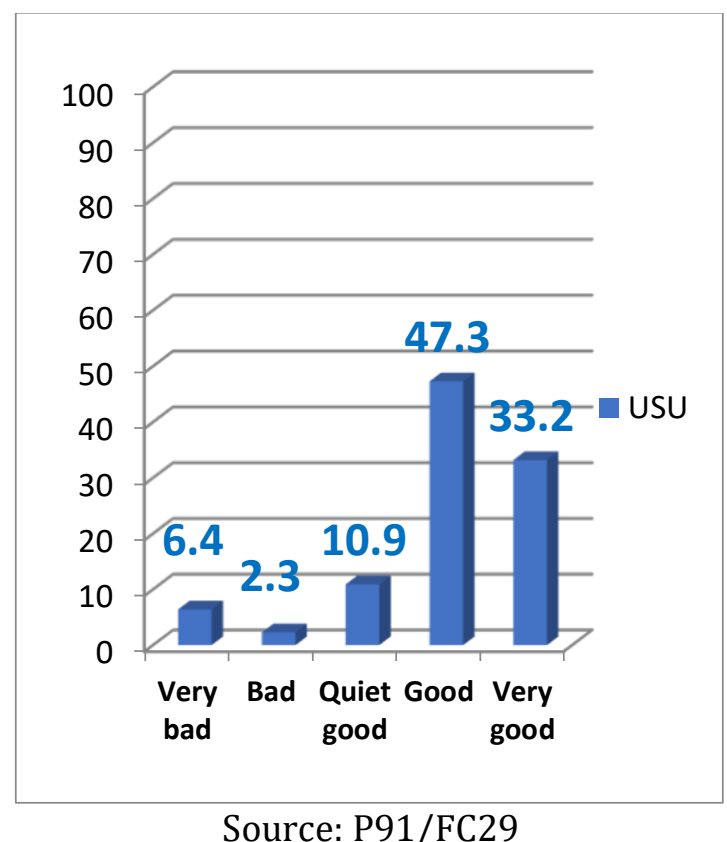

Clarity of information required by students to capture the intent of information in lecture material delivered by lecturers. Clarity of information also depends on the effective use of sentences. The use of effective sentences will arrange the information with the right target in accordance with the purpose of learning. Lecturers must have good communication skills, because with good communication skills it will cause mutual understanding of the meaning in question. This is what is then called effective communication. Lecturers should be able to communicate information that may be complicated in teaching materials such as handbooks, journals, or other articles with a more simple language so that more easily understood.

With regard to clarity of information, the results showed that as many as 47.3 percent of respondents stated that the clarity of information from certified lecturers was in the Good category, while another 33.2 percent stated Very Good. 
Chart 28

Level of adequacy of information obtained in each meeting

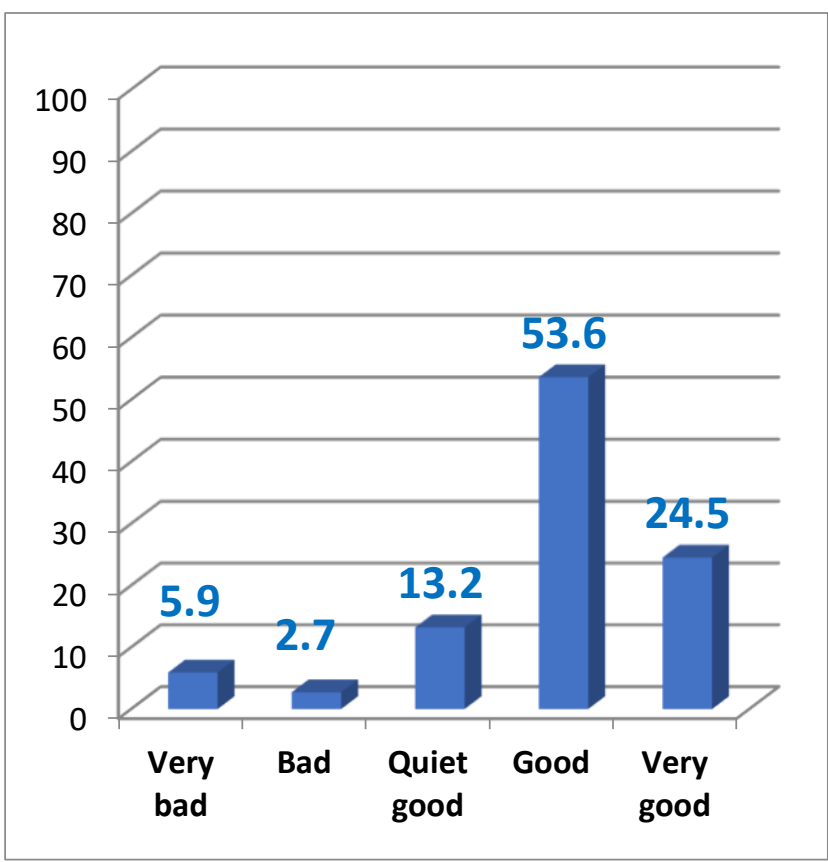

Source: P92/FC30

The adequacy of information is closely related to the clarity of the information conveyed and the completeness of handouts and other teaching materials. Given the adequacy of information then the fulfillment of information for students on the topics covered will be good. This will affect how students understand, analyze, and evaluate the learning process that takes place. These three stages, will help the ongoing lectures are effective because of the process of transfer of good science between lecturers and students. The lecturing process is said to be ideal when students are willing and able to excel at their best. To release the best ability is required encouragement / motivation from the lecturer and the adequacy of information with regard to materials, references, and other teaching materials.

The adequacy of the information obtained by the class participants is good. This can be seen from the numbers listed on the chart above. The data show that as many as 53.6 percent of respondents stated that they received adequate information. A total of 24.5 percent stated Very Good.

\section{$\mathrm{H}$ : Fulfilling Needs and Responsiveness}

Chart 29

Level of information fulfillment for each course

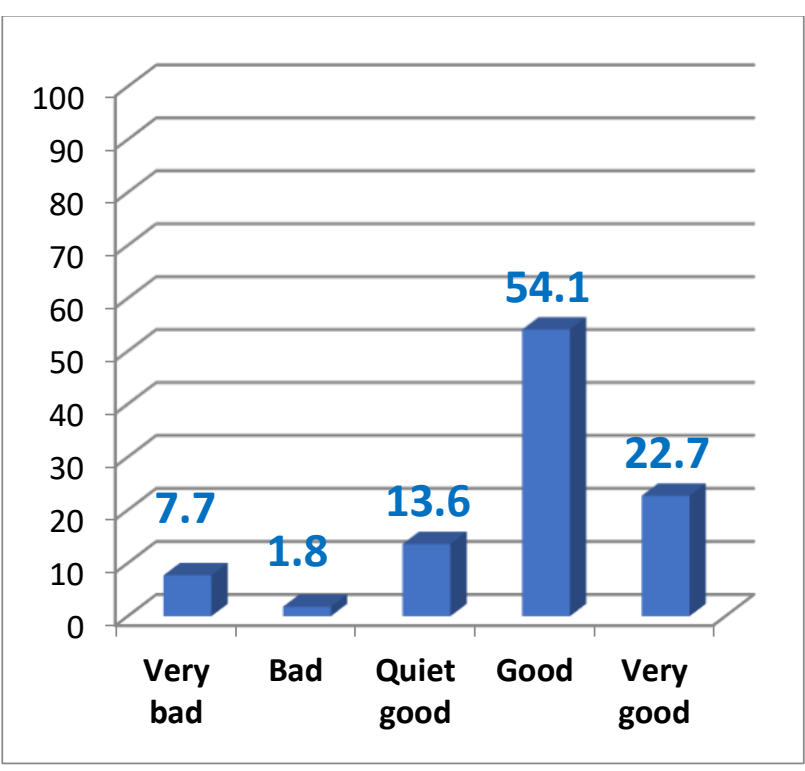

Source: P93/FC31

Information becomes an important need in the learning process. Students as class participants need sufficient information to be able to comprehend the problem in the course material comprehensively. Source of sufficiency of information not only comes from lecturers, but also from books, journals, and other teaching materials. Lecturers in this case not only act as lecturers, but also as facilitators to encourage students to explore various sources of information that can improve their knowledge, especially related to the topic of the lecture delivered.

The chart above shows that the degree of fulfillment of information in the courses taken care of by certified lecturers is good. As many as 54.1 percent of respondents stated that certified lecturers on campus have been able to meet their information needs. While 22.7 percent of others even stated Very Good 
Chart 30

Level of understanding of course materials

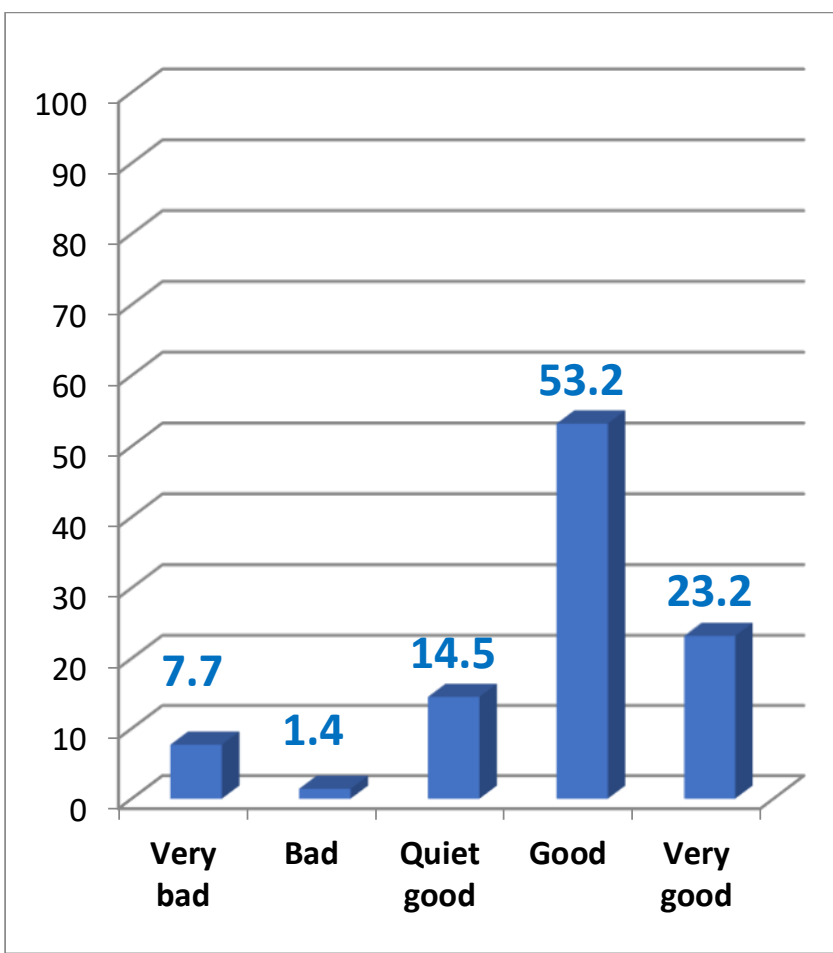

Source: P94/FC32

Based on the field data, it was found that 53.2 percent of respondents stated that their class participants could understand the material delivered by certified lecturers who nurtured the course well. Another 23.2 percent said it was very good.

Understanding the information obtained when the lectures take place effectively and efficiently. Understanding occurs when the class participants have sufficient knowledge of the ongoing lecture process and are able to explore other sources of information, which not only come from lecturers through face-to-face lectures.
Chart 31

Comfort level to ask at every meeting

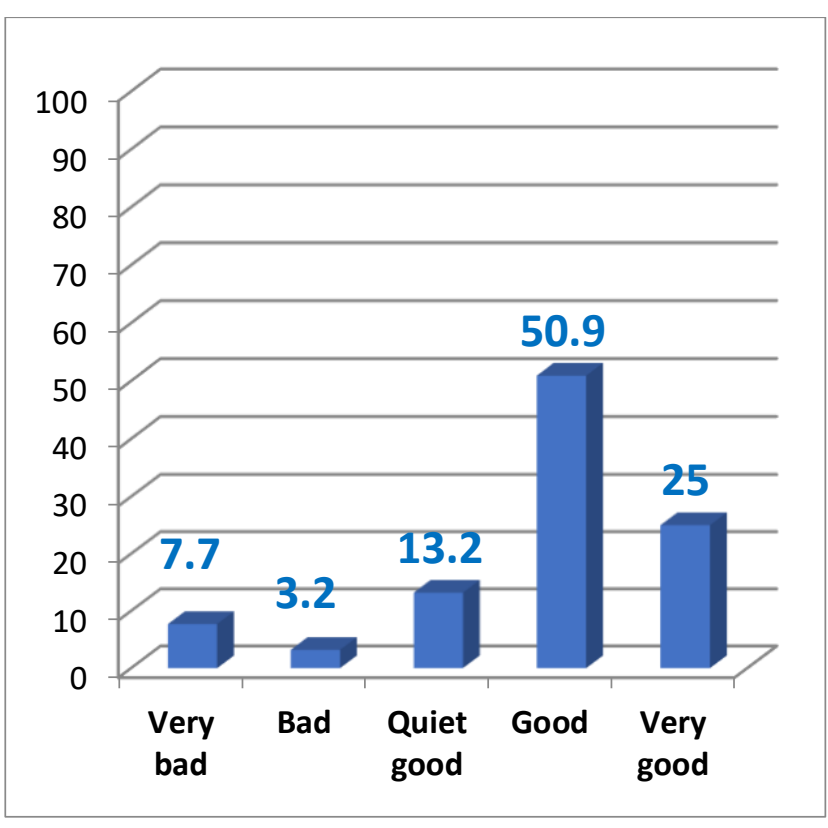

Source: P95/FC33

Freedom to ask is an important part of academic freedom. The lecturer should give a room to ask the class participants to then be able to hold discussions together. Based on tabulation of data with data as much as 50.9 percent of respondents stated that certified lecturers have given good question space to students. As many as 25 percent of others who declared the space in accordance with Very Good.

Students are comfortable to inquire while studying. Asking is an important element to see if the student is available or a source of information. In practice should be held often beginner class is reluctant to ask for fear not understand the material presented. Lecturers should be able to motivate and convince class participants, that is asking is part of the process of deepening information where class participants can be more advanced in the lecture. 
Chart 32

In General, Level of Satisfaction

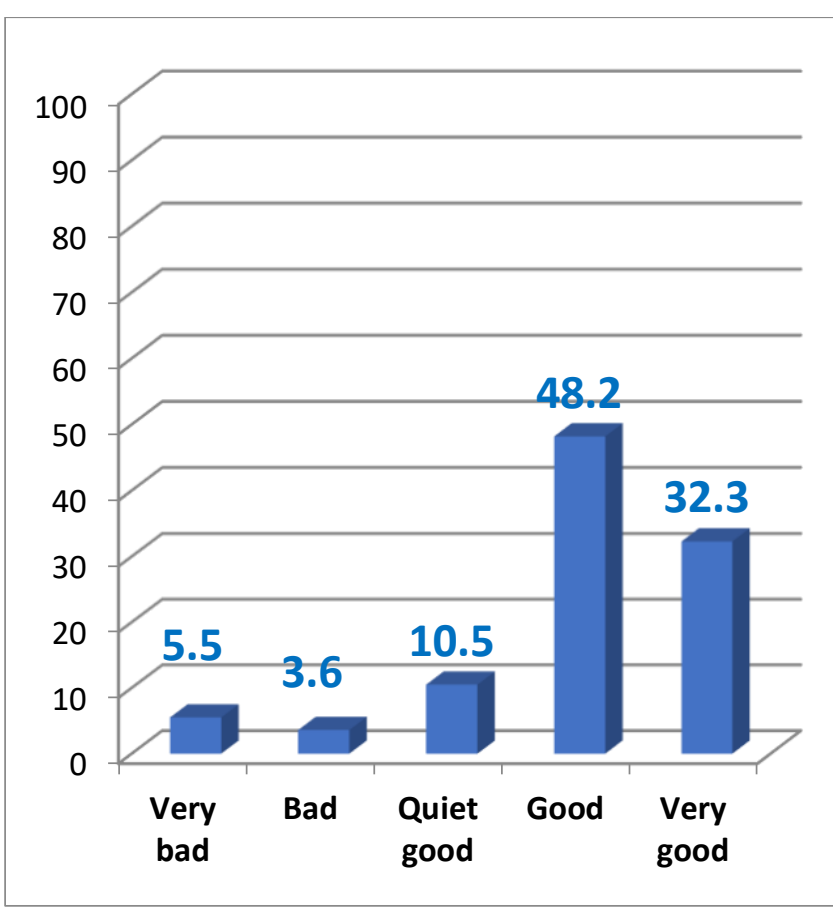

Source: P96/FC34

The chart above illustrates the general level of satisfaction of the class participants. The level of satisfaction of students who are in the Good category reached 48.2 percent, and 32.3 percent stated Very Good.

However, USU still needs to pay attention to the level of satisfaction of the class participants, because this Chart shows that the respondents who answered the category of Quiet Good is still quite high, that is 10.5 percent. Likewise respondents who stated that the level of satisfaction is very low, as much as 5.5 percent. This shows that there needs to be improvements for lecturers in terms of providing satisfaction for students.

\section{CONCLUSION}

In general, the results show that the quality of teaching and learning in Universitas Sumatera Utara is 'good'. Of the nine aspects of the study of the learning process, eight aspects are; 1) Efficiency, 2) Creativity, 3) Effectiveness of task giving and group discussion, 4) Consistency, 5) Productivity, 6) Clarity and Adequacy of information, 7) Fulfilling needs and Responsiveness, and 8) Satisfaction level, 'good' value. However, to realize the vision, mission, and educational goals in USU, then the eight aspects should be increased value to 'Very Good'. Overall, the respondents who chose the low option, even very low in the eight aspects, the percentage is still quite high.

Particularly for aspect 1) Accountability that includes; availability of GBPP/SAP, evaluation of learning outcomes, final scoring system, reference for compulsory books, technical lecture rules, return of individual/group duties, and return of UTS results to students, the respondents rated the performance of certified lecturers in this case very low.

In fact, the certified lecturers are central figures in the learning process in universities. The lecturer has the responsibility to improve the quality of the learning process in accordance with the scientific competence. Therefore, certified lecturers should work more optimally and professionally by implementing educational and teaching tasks effectively, efficiently, creatively, attractively and systematically, so that its graduates can compete. Universitas Sumatera Utara (USU) requires qualified, professional, and competent lecturers to be able to generate intellectual generation in accordance with the vision and mission of Universitas Sumatera Utara. Therefore, the results of this study is expected to be an input for USU in making policies, especially the application of evaluation for certified lecturers at USU.

In accordance with educational purposes in USU and national education objectives namely; educate the life of the nation and develop a complete Indonesian human that is; human beings who believe and piety to God Almighty and virtuous noble character, possessing knowledge and skills, physical and spiritual health, a stable and independent personality and responsibility of society and nationality.

To achieve this, Universitas Sumatera Utara as one of the institutions of higher education must be responsible and evaluate, encourage and facilitate certified lecturers to constantly improve their competence and performance optimally, improve the curriculum, equip facilities and pre-learning tools. Thus, outcomes from USU are in accordance with societal needs, industrial/business needs, and professional needs; with the understanding that outcomes are the ability to integrate intelectual skills, knowledge and affective in a whole behavior. 


\section{REFERENCE}

Arikunto, (2004), Dasar-Dasar Evaluasi Pendidikan,

Bumi Aksara

Eley, M.G. (1993). Differential study approaches within

(Ed.).

individual students. Dalam A.R. Viskovic

Research and development in the higher education (vol 14 hal 75-82). Australia: HERSDA

Kirkpatrick, D.L. (1998). Evaluating training program,

Fransisco:

The four level, Second edition. San Berret-Koehler Publisher, Inc.

Kirkpatrick, sumber:bussinessball.com/kirkpatricklea rnin gevaluationmodel.htm; download 28 November 2014)

PAU-PPAI. (1996) Mengajar di Perguruan Tinggi, Direktorat Jenderal Perguruan Tinggi.

Robinson, Bernadette, (2002), The CIPP Approach to Evaluation.

Sekaran, Uma. (1991). Research method for Bussiness.

Stark, J.S. \& Thomas, A. (1994).Assesment and program evaluation. Needheim Heights:

Simon

\& Schuster Custom Publishing.

Stufflebeam, Daniel L \& Anthony J. Shinkfield, (1985),

Theory

Sytematic Evaluation: A Self Guide to and Practice, Kluwer-Nijhoff Publication.

Sujana, Nana \& Ibrahim.(2004). Penelitian dan penilaian pendidikan. Bandung: Sinar

Baru

Algesindo.

Tim Penyusun. (2014). Evaluasi Diri: Analisis Situasi dan Pemosisian USU
Tim Kerja. (2005). Tanya Jawab Seputar Kurikulum Berbasis Kompetensi ( KBK) di Perguruan Tinggi. Dirjen Pendidikan Tinggi. Depdiknas.

Woolfolk, A.E \& Nicolich, L.M. (1984).Educational pshycology for teacher. Englewoods Cliffs: Prentice Hill Inc. 